\title{
Farm wage and Rice Price dynamics in Bangladesh
}

\author{
Md. Fuad Hassan ${ }^{1,2}$ (D) $\cdot$ Lukas Kornher ${ }^{2}$ (D) \\ Received: 19 November 2020 / Accepted: 14 June 2021 / Published online: 20 July 2021 \\ (C) The Author(s) 2021
}

\begin{abstract}
Empirical findings explaining the wage-price nexus in Bangladesh are diverse and conflicting. A proper understanding of the relationship between food prices and farm wages is essential for planning policies in support of the wellbeing and food security of the rural poor. In exploring the link between food prices and rising agricultural wages, this study analyzes the dynamic relations between those two by using monthly data from 1994 to 2014. A standard vector error correction model (VECM) is implemented to determine the short-run and long-run relationships between wages and food prices in eight divisions in Bangladesh. In addition, we use autoregressive distributed lag (ARDL) models to estimate the pass-through coefficients and to compare the short-run effects of rice price and urban wage shocks on agricultural wages. We find statistical evidence for a structural break between January 2007 and January 2009 in the relationships of the variables in all divisions. Different to the period until 2007/2009, after the structural break, in six out of eight divisions, rice price shocks do not transmit to the farm wages in the short-run. Moreover, our findings show that in the long-run food prices have become less influential in explaining the changes in farm wages while the influence of urban wages has become stronger in some divisions.
\end{abstract}

Keywords Agricultural wages $\cdot$ Rice prices $\cdot$ Lewis transformation $\cdot$ Rural labor markets $\cdot$ Bangladesh

\section{Introduction}

It is one of the primary objectives of low-income countries to achieve economic development. To improve the well-being and socio-economic conditions of the population, it is essential to create employment opportunities. However, rising food prices in recent years have created serious concern about rising poverty and food insecurity in the developing world (Barahona \& Chulaphan, 2017). Against this background, there is also the view that farm households in developing countries, who are not only consumers but also food producers, could benefit from higher prices, yet the magnitude of such benefits is controversial (Ivanic \& Martin, 2014). However, projections of benefits for producers are based on

Md. Fuad Hassan

fuadstat@gmail.com; fuad.stat@bau.edu.bd

Lukas Kornher

lkornher@uni-bonn.de

1 Department of Agricultural and Applied Statistics, Bangladesh Agricultural University, Mymensingh 2202, Bangladesh

2 Center for Development Research (ZEF), University of Bonn, Genscherallee 3, 53113 Bonn, Germany the assumption that higher food prices one-to-one translate to higher wages.

In Bangladesh, the agricultural sector provides both food and employment for the population. In the fiscal year 201819 , its contribution to the GDP was about $13.65 \%$, with an annual growth rate of about 3.92\% from 2018 to 2019 (BBS, 2019). The provisional estimates for the fiscal year 2017-18 showed that the manufacturing and construction sectors had grown by about $13 \%$ and $10 \%$ in 2017 , respectively (BBS, 2018). Most of the unskilled and semi-skilled laborers are involved in both agriculture and non-agriculture activities, i.e., providing manual labor in crop production and industries. In many developing countries, the responsiveness of wages to prices determines how the standard of living of the poor evolves (Boyce \& Ravallion, 1991; Ivanic \& Martin, 2008). The importance of the link between farm wages and food prices is also reflected in national statistics. In Bangladesh, the bottom 5\% income group among rural households spends $61.4 \%$ of their total consumption expenditure on food (BBS, 2016a) and in consequence, large spikes in food prices are a serious threat to this group (Von Braun \& Tadesse, 2012; Tadesse et al., 2016). Among the different food grains, rice alone is consumed by more than $90 \%$ of the population, and it covers $75 \%$ of the total cropped land (BBS, 2016b). Rice farming is the largest activity in the agricultural sector, 
employs about $45 \%$ of the rural labor force, and also provides two-thirds of the caloric requirements of the nation. Thus, it is very likely that changes in rice prices will have a significant impact on agricultural wages, poverty, and food security.

In the long-run, the farm wage rate reflects the level of agricultural productivity (Hossain, 2008), however, the structural transformation process in many less-developed agrarian economies is characterized by strong changes in the agricultural sector, and wage rates may not quickly adjust to the new equilibrium. This can be both a cause and a consequence of imperfections in food and labor markets (Timmer, 1988). However, the structural transformation of agrarian economies into industrialized and service-oriented economies is the key to sustainable development. The reallocation of labor from agriculture to other sectors of the economy is one of the aspects of economic growth. In this way, increases in urban wages may transmit to higher farm wages (Headey et al., 2012). Exploring the relationship between agricultural and non-agricultural wages as well as staple food prices is an important empirical issue, particularly in view of such a transformation of the economy, for planning proper policies to support the poor. Soaring food prices in the last decades have caused the government to introduce interventions (e.g., rice distribution at a subsidized rate, controlled imports, and subsidized production). These interventions are based on good intentions but do not always improve the situation in a sustainable manner (Kalkuhl et al., 2016). This signifies the importance of providing empirical evidence on the welfare implications of rising prices to support policymaking.

The determination of the welfare effect of increasing food prices and wage changes in less developed countries requires the determination of wage-price elasticities among the rural poor. The quick or sluggish adjustment of wages to rice prices may have positive or detrimental effects on the poor because physical labor is the primary source of their earnings. Jacoby (2016) empirically estimated that farm wages in India respond to price increases, in particular, if the share of the particular food crops, whose prices change, is large. In this way, increasing food prices may improve well-being of agricultural households. This finding is supported by Lasco et al. (2008) and Headey (2014), who estimated wage-food rice price elasticities for Indonesia and Ethiopia, respectively. In both cases, the elasticity is close to unity. Hence, a food price increase is associated with an equal increase in purchasing power.

Based on these findings, several studies (e.g., Ivanic \& Martin, 2014) conclude that soaring food prices have limited effects on rural poverty. For instance, Ivanic and Martin (2014) assumed a medium-run wage-price elasticity of 0.6 for Bangladesh. However, those studies have some theoretical and conceptual limitations as they assume an instantaneous price-wage transmission in a general equilibrium framework. If wages respond inelastically to a change in rice prices in the short-run, then rural workers, who offer their labor on farms and who are net buyers of rice, will not be able to purchase as much rice as prior to the price change. Conversely, net sellers of rice will be able to hire more labor for rice cultivation and realize greater net income. The opposite is true if wages respond elastically to price changes. Further, they ignored the possibility of structural breaks in the relationship between wages and prices.

Bangladesh's economy has experienced a structural transformation. The country is projected to advance from the status of a least developed country to a developing country in 2024 (Zhenmin, 2018). Within the past ten years, this has contributed to a sharp increase in farm wages, which almost closed the gap between rural and urban wages. Earlier studies (Rashid, 2002; Zhang et al., 2014) suggest that neither the neoclassical theory of labor nor the efficiency wage hypothesis is consistent with the recent trends. Instead, unlike in many other Asian countries, the structural transformation in Bangladesh follows the prediction of the Lewis (1954) model. The Lewis turning point is reached when farm wages increase in consequence of labor migration to the industrialized sectors.

The primary objective of this research is to understand the relationship between food prices, urban wages, and farm wages. This will enable us to comment on the extent to which the process of structural transformation in Bangladesh has advanced. Furthermore, we formally tested the Lewis hypothesis by examining the existence of a structural break in the relationship between rural and urban wages, the so-called Lewis turning point. For these purposes, standard time series econometrics was applied, which also allowed us to answer the central research questions in this study, including: (i) Does the agricultural wage rate respond to changes in rice prices or is there any one-to-one response? (ii) Are agricultural labor markets independent of urban labor markets? (iii) How fast do farm wage rates adjust in response to changes in rice prices and urban wages?

This paper attempts to resolve the shortcomings of previous studies on the interlinkages between food prices and wages in Bangladesh. Within the existing literature, little attention has been given to understanding the wage-price responsiveness at sub-national levels, which would be essential to investigate to properly assess related policy implications and allows for heterogeneity across geographical units. In doing so, we also updated early studies on wage formation in Bangladesh (e.g., Boyce \& Ravallion, 1991; Rashid, 2002) by using a unique data series of prices and wages from 1994 to 2014. The utilization of such a long data series facilitates a reliable and meaningful interpretation of changes in wageprice elasticities over time and their implications regarding the structural transformation of the Bangladeshi economy. Most of the existing literature is limited to descriptive analysis (e.g., Zhang et al., 2013). Closely related to the present work, the study by Zhang et al. (2014) discussed the structural 
transformation of labor markets in Bangladesh. However, their analysis focused on the welfare implications of this fundamental transformation process, and they considered the drivers of the structural change within a conceptual framework without the help of econometric tools. We close this gap by exploring the present trend of staple food prices and agricultural wages in Bangladesh empirically. Findings from this study will therefore help to establish whether rice price is still a significant determinant of rural welfare and poverty reduction, whether the government should continue to control the food price to reduce rural poverty, or whether it would be more beneficial to instead foster off-farm employment.

The remainder of the paper is structured as follows: Section 2 presents and discusses a brief overview of the structural transformation process in Bangladesh using descriptive statistics. In Section 3, the methodology and the data set are described. The presentation of the results and their discussion follows in Section 4. Section 5 concludes this paper and provides some policy recommendations.

\section{Structural transformation in Bangladesh}

A country's economic development is strongly related to the structural transformation of the economy. In this process, the labor force moves from the primary, which includes the agricultural sector, into more productive industrialized sectors. In the course of this structural transformation process, the migration of workers to the non-agricultural sectors is said to reduce the downward pressure on farm wages (Nonthakot \& Villano, 2008). However, there is not much support for this hypothesis looking at historical wage data for Bangladesh. Bose (1968) showed that real agricultural wages in Bangladesh reduced after the end of colonization. Later studies observed a decoupling of farm wages from agricultural prices in the late twentieth century (Boyce \& Ravallion, 1991; Rashid, 2002). Figure 1 shows the distribution of Bangladesh's labor force between 1995 and
2015. It is apparent that the agricultural labor force increased until the 2002-2003 labor force survey. Thereafter, migration flows from agricultural into the manufacturing and construction sector can be observed. In Fig. 2 we demonstrate the eight divisions of Bangladesh. This shift of labor away from agriculture had positive effects on the development of farm wages (Zhang et al., 2014). In addition, agricultural wages grew much faster than urban wages. Moreover, Fig. 3 illustrates that the growth in wages was not accompanied by a similar increase in food prices. Hence, real wages also grew. The food wage, which we define as the ratio between wages and the price of the most important staple commodity rice, doubled between 1995 and 2015.

In the meantime, farm wages in Bangladesh rose faster in the second half of the 2000 s than before, i.e., the average male farm wage rose in real terms by $45 \%$ between 2005 and 2010 (Wiggins \& Keats, 2014). Furthermore, the booming manufacturing sector also increased the wages of urban laborers and attracted surplus labor from rural sectors. Since physical labor is the primary productive asset for the rural population, an increase in real wages is associated with an improvement in rural livelihood and poverty reduction. The recent estimate reveals that poverty dropped by $17 \%$ within the last decade (Hill \& Genoni, 2019). This was mainly driven by the reduction of rural poverty. Zhang et al. (2014) examined the sources of the poverty reduction by using householdlevel data. According to their estimation, poverty would have decreased by only $7.3 \%$ if agricultural wages had not changed. Alongside the importance of remittances, farm wage growth was the main driver of poverty reduction in Bangladesh.

Before the 1990s, Bangladesh rice market was isolated from the international markets. Trade liberalization during the 1990s helped to reduce production cost and raised profitability of the rice sector (Ahmed, 1999). Private businesses played a great role in responding quickly to the market demands through rice imports, mainly from India. However, supported by the National Food Policy Plan of Action
Fig. 1 Distribution of labor force above 15 years; source: Author calculation based on BBS data

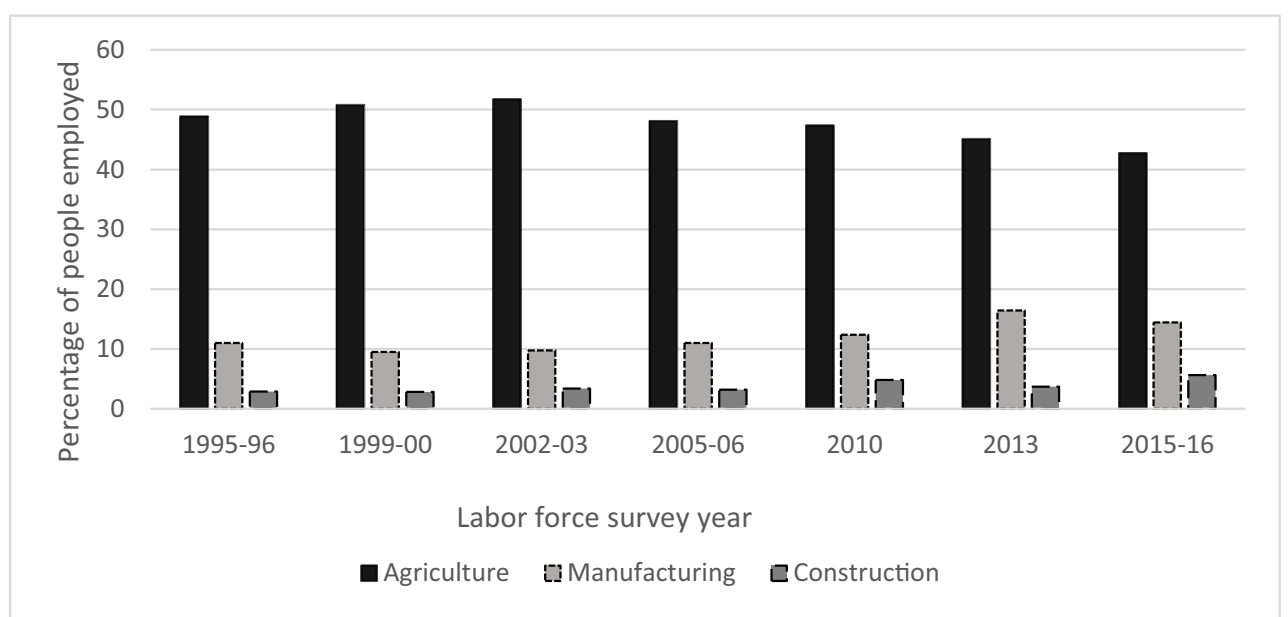


Fig. 2 Divisions of Bangladesh; Source: Author's illustration based on Humanitarian Data Exchange (2021)

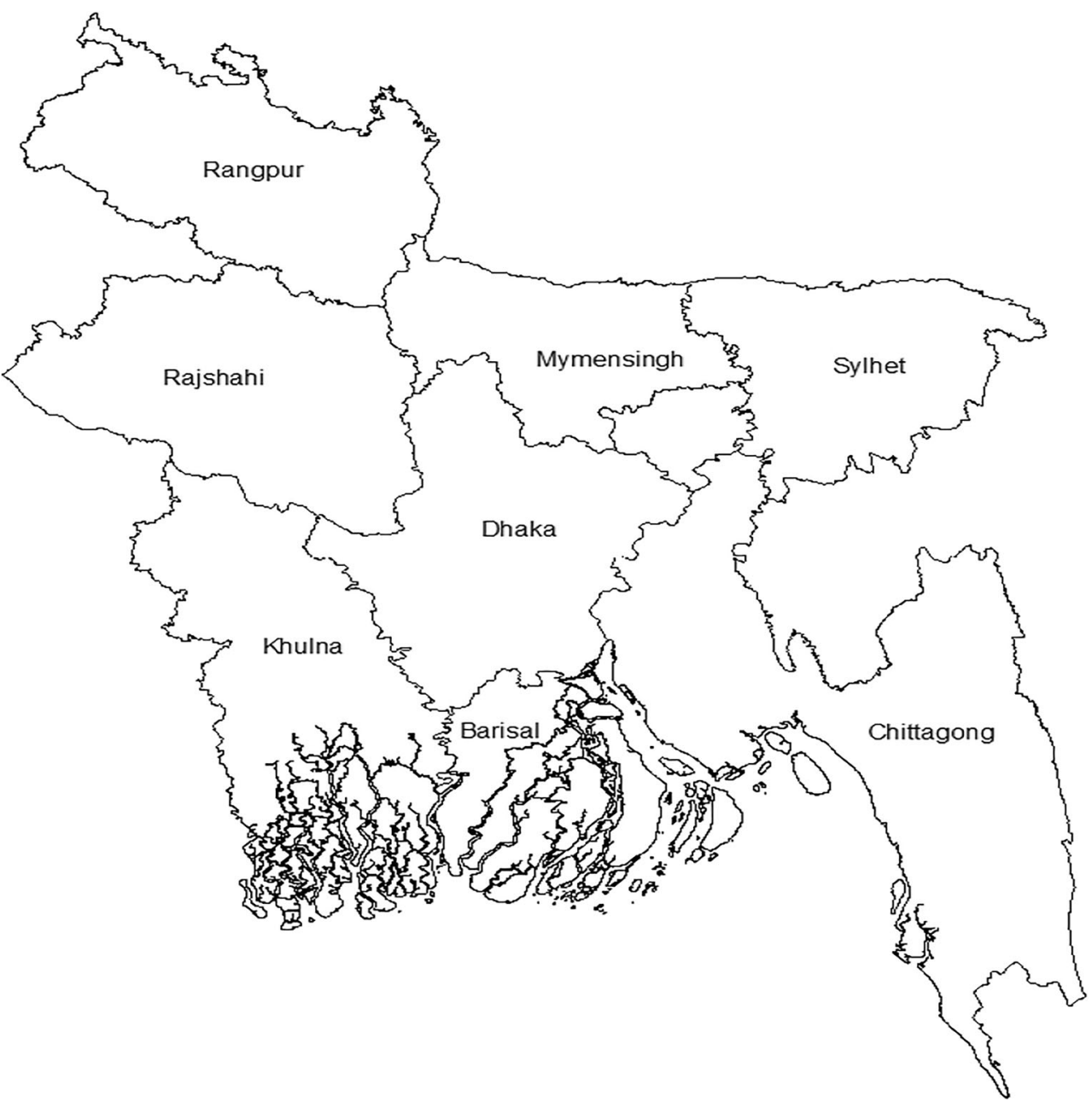

(2008-15), which ensures that farmers do not produce at a loss by providing them with a support price higher than the cost of production, public involvement in the rice markets remains substantial. The objective of the public foodgrain distribution system (PFDS) in Bangladesh is to build rice stocks for an emergency, like India's rice export ban in 2008, and to provide income support to farmers. The distribution works through a rationing system which has been introduced to distribute or collect rice at fair prices to protect poor consumers and marginalized farmers.

As in many other countries, the world food crisis in 2007/ 2008 also had a dramatic impact on food security and poverty in Bangladesh. Since 2007, there have been two major price shocks (2008 \& 2011) in the food markets in Bangladesh (Hossain, 2012). Food wages for agricultural and urban laborers in all divisions exhibited a sharp dip during this period as illustrated in Fig. 3. However, in the aftermath of the global financial and economic crisis, rice prices went down in 2010 and recover later (Jayasuriya et al., 2012). From the very beginning of trade liberalization, Bangladesh heavily imported rice from India, Thailand, and Vietnam (Akhter, 2017). Empirical analysis suggests a large transmission of international price shocks to domestic rice markets in Bangladesh (Murshid \& Yunus, 2018). More recently, international food prices experienced a decline of $14 \%$ between 2013 and 2015, sliding into a five-year low, which consequently impacted food prices in Bangladesh because of the availability of cheaper imports (World Bank Group, 2015). Agricultural policies have been put in place to address these issues. This led to a substantial increase in public rice stocks. For instance, Open Market Sales (OMS) reached 13.8 million people by distributing $5 \mathrm{~kg}$ of rice per person per day at subsidized rates during the price shock in 2008 (Grosh et al., 2011).

Besides policies keeping prices of staple low to make it affordable, there are also those that address labor market issues. For instance, minimum wages have been set for selected industries, most importantly the garment sector, currently amounting to USD \$68 per month (Adnan, 2018). However, since the wages are not updated regularly, there is little evidence on how wages in other sectors responded. Further, unemployment rates did not respond to increases in the minimum wage ( Liton et al., 2018). The employment generation program (EGP) has been 


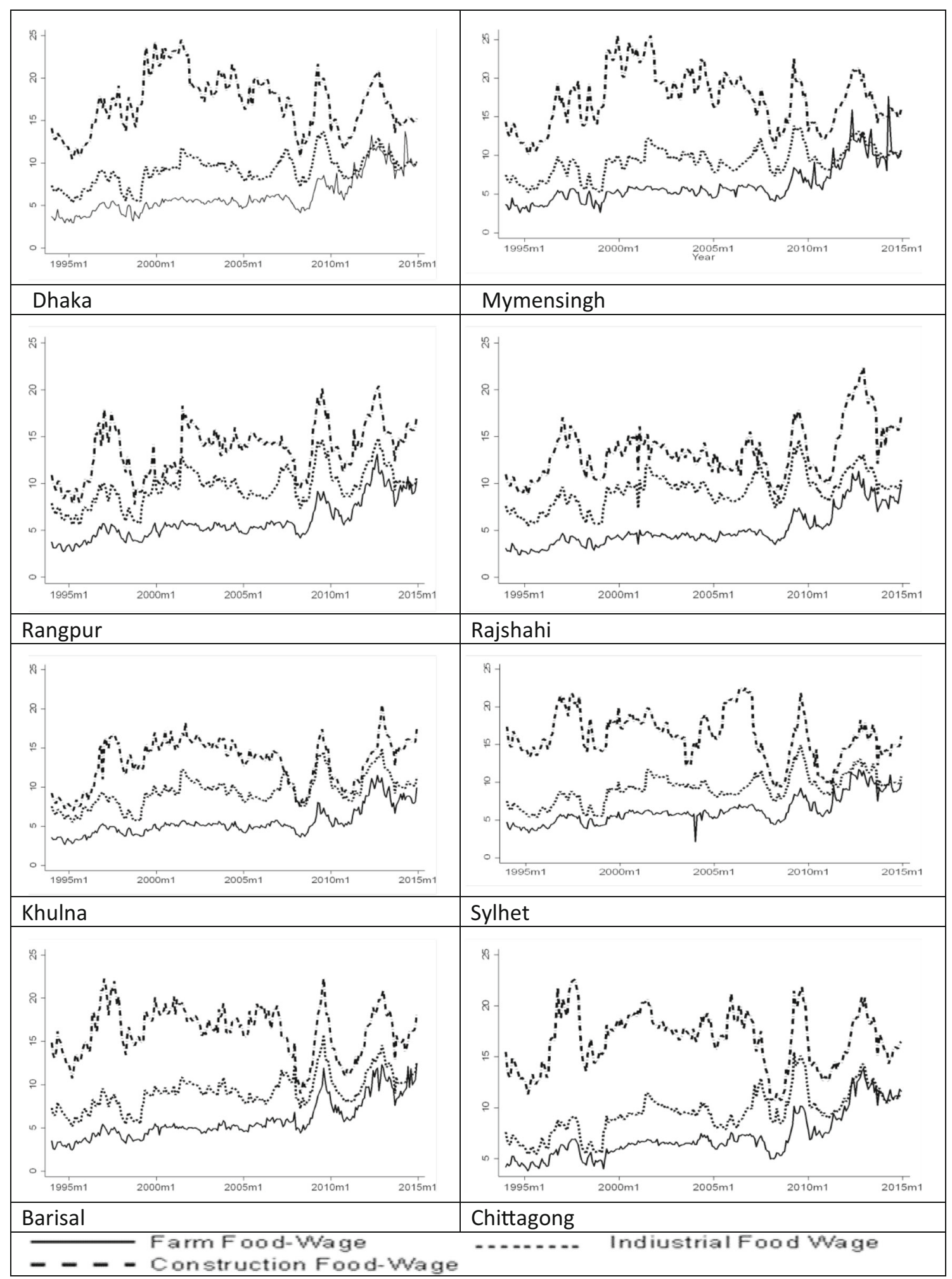

Fig. 3 Food wage for farm, construction and industrial wage. Note: Food wage is the ratio of the wage rate (farm, construcution, and industrial) divided by the rice price and normalized at $1 \mathrm{~kg}$ of rice

running since 2009 to support the poor, unemployed rural people during lean seasons. The program is implemented with the support of the World Bank. The extent of such policies and strategies are ongoing, but their successful implementation may depend on the proper intervention at the proper place with efficient management. 


\section{Methodology}

The main objective of this paper is the analysis of the development of farm wages and the wage-price pattern in the longand short-run. For this purpose, we applied a standard time series econometrics approach, which includes the testing for the existence of a long-run relationship between the variables. The results of Johansen's rank test subsequently informed the way we modeled the wage-price relationship, either in error correction form or within the framework of an autoregressive distributed lag model. In order to calculate comparable shortand long-run adjustment values, we used the ARDL model to compute pass-through coefficients for different periods. The procedure is explained in detail in the following sections.

\subsection{Empirical framework}

A stochastic process is said to be stationary if its mean and variance are constant over time. However, most macroeconomic series are non-stationary. If the time series variables are non-stationary, fitting a regression model produces " $t$-ratios" that will not follow a standard $t$-distribution, and thus create spurious regression results (Engle \& Granger, 1987). In less technical terms, a common underlying trend may create a statistical relationship even if there is no causal relationship between the variables. In consequence, normal regression methods like ordinary least square OLS are not applicable in the presence of unit root. Thus, the stationarity of the time series needs to be examined first (Maddala et al., 2007). Examining the trends in farm and urban wages as well as rice prices, which are shown in Fig. 3 for all divisions farm wage is indicated by the blue line, caused us to strongly suspect nonstationarity in at least one of our variables of interest. By using the unit root test, this can be statistically tested. The lag lengths used in the test were determined by the information criteria $\mathrm{AIC}$ or BIC.

Two non-stationary series are said to be co-integrated if both series are integrated of the same order. If the unit root tests suggest the presence of a unit root in the series, then we need to check the order of integration necessary to make the series stationary, which should be the first step to choosing an exact model. The majority of the macroeconomic variables become stationary after observing their first differences, which makes them integrated of order 1 , written as $I(1)$. If all the variables under the considered function are integrated of order 1, then we can check for the cointegration rank. The cointegration relationship between the variables of interest is analyzed using the Johansen cointegration method. The rank test of Johansen relies on the relationship between the rank of a matrix and its characteristic roots. Once cointegration is established, a long-run relationship among a set of nonstationary variables exists which always brings the variables back onto their long-run equilibrium path (Enders, 2010).
Whenever the cointegration rank test confirms the existence of at least one rank, the vector error correction framework should be used. Otherwise, the alternative option available is a simple vector autoregressive model (VAR).

The simple form of vector autoregression (VAR) $Y_{t}$ of $n$ endogenous variables consisting of lags up to $k$ is given below:

$Y_{t}=\alpha_{t}+H_{1} Y_{t-1}+H_{2} Y_{t-2}+\ldots+H_{i} Y_{t-k}+\epsilon_{t}$

Where $Y_{t}$ is the $(n x 1)$ vector and each $H_{i}$ is a $(n x n)$ matrix. $\alpha_{t}$ is a vector of constants and $\epsilon_{t}$ is a vector of residuals.

The corresponding vector error correction model (VECM) is (Harris \& Sollis, 2005):

$$
\begin{aligned}
\Delta Y_{t}= & \alpha_{t}+\varphi_{1} \Delta Y_{t-1}+\varphi_{2} \Delta Y_{t-2}+\ldots+\omega_{k-1} \Delta Y_{t-k+1} \\
& +\theta_{i} Y_{t-k}+\Gamma+\epsilon_{t}
\end{aligned}
$$

Where $\varphi_{1}=-\left(I-H_{1}-H_{2}-\ldots-H_{i}\right)(i=1, \ldots, k-1)$ and $\theta=-\left(I-H_{1}-H_{2}-\ldots-H_{k}\right)$. The above model consists of long-run and short-run information to changes in $\Delta Y_{t}$ through estimated $\varphi_{1}$ and $\theta$. In general, $\theta=\delta \beta$ is a square matrix where $\delta$ is the speed of adjustment and $\beta$ is the matrix of coefficients generating long-run equilibrium (Patterson, 2000).

On the other hand, if some of the series are $I(1)$ and some are $I(0)$, it is suggested to use the ARDL model (Pesaran et al., 2001). However, the ARDL cannot be used if any of the series in the model has integration of order $I(2)$. The autoregressive model (ARDL) for $k$ month lags can be postulated as:

$$
\begin{aligned}
\Delta W a= & \alpha+\sum_{i}^{k} \alpha_{i} \Delta W a+\sum_{i}^{k} \beta_{i} \Delta P_{t i}+\sum_{i}^{k} \gamma_{i} \Delta W I_{t i} \\
& +\sum_{i}^{k} \delta \Delta W C_{t i}+\epsilon_{t i}
\end{aligned}
$$

Where, $W a$ stands for farm wages, $P_{t i}$ is the rice prices, and $W I_{t i}$ and $W C_{t i}$ indicate industrial and construction wages. All variables are measured in real terms deflated by the rural and urban consumer price index.

In addition to modeling the long- and short-run adjustment in the cointegration format, it is worth comparing the impact of changes in urban wages and rice prices on agricultural wages for different time horizons. Varying the lag structure allows this to be done in the ARDL framework (Ianchovichina et al., 2014). ARDL models with alternating lag structure will be quite meaningful for detecting immediate pass-through effects. The respective pass-through coefficient for $k$ periods can be computed from eq. (3) as $=\frac{\sum_{i}^{k} \beta_{i}}{1-\sum_{i}^{k} \alpha_{i}}$.

For long-term time series, it is also essential to check whether the coefficients are constant throughout the whole period. This is because long time series data is often subject to structural breaks. Structural breaks likely occur when a time series abruptly changes its mean or other parameters at a point in time (Campos et al., 1996). In the context of a developing 
country, such as Bangladesh, the main reasons for a structural break are related to changes in government policies, domestic or international shocks of both natural and human origin as well as structural changes in the economy. Ignoring the presence of structural breaks might influence the outcome of the unit root test and steer incorrect parameter estimation (Akhter, 2017). The existence of a structural break was tested in two ways. Firstly, for all series of the eight divisions, we performed the Supremum Wald test for a structural break at an unknown break date. Secondly, we performed a series of likelihood-ratio (LR) tests to verify the stability of the coefficient estimates in a time-series regression over different periods defined by possibly known break dates (Maddala et al., 2007).

\subsection{Data sources}

The statistical models used in this study rely on a comprehensive database covering monthly data for the period between 1994 and 2014. At present, Bangladesh is divided into eight major divisions (Fig. 2) and 64 sub-divisions (districts). The BBS collects data on wages at the district level on a regular basis and publishes them in the Monthly Statistical Bulletin. All the wages are measured in Bangladeshi Taka (BDT) per day. Farm wages represent daily agricultural wages (male, without a meal) including key agricultural activities like harvesting or transplanting. We introduce two types of urban wages, industrial and construction. The wage of a construction laborer was estimated by considering the average daily wage of carpenters, masons, and brick breakers. Industrial wage rates include the aggregate monthly average of the daily wage in cotton manufacturing, textile, and jute industries. For some divisions urban wage data are not available before 2010; in this case they were replaced by values obtained from the major towns in the geographically nearest area. ${ }^{1}$

The statistical bulletins also include information on the nation-wide consumer price index (CPI), which we used to deflate prices and wages. Rice prices at wholesale level were collected from the Food Planning and Monitoring Unit (FPMU) and the Department of Agricultural Marketing (DAM). We considered the coarse rice price that is available in each district during the respective rice marketing seasons (Aus, Aman, Boro). ${ }^{2}$ Unlike in many related studies, the construction of the price series took into account the seasonal market availability of a specific category of rice, i.e., coarse

\footnotetext{
${ }^{1}$ Until 2010, the sample consisted of 23 districts only; only thereafter was the sample expanded. To maintain the same frequency, this analysis utilized aggregated wages that is the simple average of the districts, and prices for all eight divisions of Bangladesh.

2 Aus: rice sown in summer (May) during pre-monsoonal rains and harvested in autumn (July) is called Aus rice. Aman: rice sown in the rainy season (JulyAugust) and harvested in winter (November) is called Aman rice. Boro: rice sown in winter (November) and harvested in summer (March-April) is called Boro rice.
}

rice, by averaging the prices of the seasonal type of rice avialble in the market at that time. ${ }^{3}$ Coarse rice varieties during "Boro" and "Aman" seasons are available in most months of a year, while rice produced in "Aus" season is only available during the season, which is consistent with its low production rate all over the country. Before averaging wholesale prices at the division level, missing values of district level rice prices were replaced by interpolation. The summary statistics (mean) of the major variables over the 24 years across the divisions are displayed in Table 1 , which clearly indicate a shift in wage and price regime after 2005. However, there are certain similarities as well as differences between the divisions. In general, the eight divisions are situated in eight different agro-ecological zones of Bangladesh (AEZ) and have varying rates of poverty. Household income and expenditure survey (HIES) data from 1991 to 2015 were utilized to obtain in-depth knowledge of the poverty situation at the subnational level of Bangladesh. Complete data of the past poverty rates of the Sylhet division are not available from HIES for a few of the survey rounds.

We found similarities between Dhaka and Mymensingh, Rajshahi and Rangpur, and Barisal and Chittagong in terms of wages and prices. In terms of general poverty, Rajshahi was the poorest division during the 1990s, and then the poverty line reduced between 2005 and 2010 (BBS, 2010a). Farm wages were higher in the Chittagong and Dhaka divisions than in the other regions. In contrast to the other divisions' average rice prices, urban wages were higher in Dhaka, Sylhet, and Chittagong. Nominal farm wage doubled between 2005 and 2010, and it increased by $73 \%$ between 2010 and 2014. Real farm wages also jumped in the period from 2005 to 2010, for example, from 87 BDT to 125 BDT in the Dhaka division. Both farm and urban wages experienced a similar shift between 2005 and 2010, with their pace of growth slightly diminishing between 2010 and 2014. Similarly, nominal rice prices increased significantly from 2005 to 2010 . However, from 2009 to 2014, the increase in rice prices was low, while the average rice price decreased from 17.56 BDT to 15.14 BDT in Dhaka.

Since 1990s, it is clear that the incidence of poverty both in the upper and lower poverty lines following a downward trend (BBS, 2016a). The Rajshahi division, ${ }^{4}$ located in the northern part of the country, had a higher poverty rate than the others. Over time, however, the poverty rate lowered drastically in this northern region, whereas the rate of poverty reduction was slow in Khulna from 1990 to 2005. From Technical Appendix 5 , it is evident that the country as a whole experienced a

\footnotetext{
${ }_{3}^{3}$ Although it seems more appropriate to use weighted average (to consider seasonal availability of rice) than the simple average to construct wholesale prices, we opted for simple average to avoid making uninformed assumptions about the relative supply of the different seasonal rice in the market.

${ }^{4}$ The greater Rajshahi division later split into two, the Rajshahi and the Rangpur division.
} 
Table 1 Wages and rice price over the 25 years in BDT

\begin{tabular}{|c|c|c|c|c|c|c|c|c|c|c|}
\hline \multirow[t]{2}{*}{ Divisions } & \multicolumn{2}{|l|}{1995} & \multicolumn{2}{|l|}{2000} & \multicolumn{2}{|l|}{2005} & \multicolumn{2}{|l|}{2010} & \multicolumn{2}{|l|}{2014} \\
\hline & Nominal & Real & Nominal & Real & Nominal & Real & Nominal & Real & Nominal & Real \\
\hline \multicolumn{11}{|l|}{ Dhaka } \\
\hline Farm wage & 43.56 & 67.38 & 63.91 & 77.78 & 84.63 & 81.37 & 188.71 & 125.27 & 334.83 & 164.95 \\
\hline Industrial wage & 75.45 & 117.39 & 107.78 & 132.84 & 129.68 & 278.12 & 261.72 & 176.67 & 320.71 & 160.50 \\
\hline Construction wage & 141.44 & 220.31 & 264.44 & 325.97 & 283.97 & 187.23 & 372.01 & 255.48 & 485.68 & 243.48 \\
\hline Rice price & 12.48 & 19.22 & 11.74 & 14.13 & 15.64 & 14.92 & 27.98 & 17.56 & 32.53 & 15.14 \\
\hline \multicolumn{11}{|l|}{ Mymensingh } \\
\hline Farm wage & 43.05 & 66.67 & 63.61 & 77.38 & 82.63 & 79.43 & 183.86 & 121.97 & 342.17 & 168.62 \\
\hline Industrial wage & 75.45 & 132.32 & 107 & 167.90 & 129.68 & 270.68 & 261.35 & 157.29 & 321.24 & 160.50 \\
\hline Construction wage & 139.68 & 227.10 & 235.48 & 283.55 & 285 & 186.56 & 370.42 & 227.63 & 464.41 & 210.04 \\
\hline Rice price & 12.72 & 19.59 & 11.70 & 14.09 & 15.23 & 14.53 & 28.21 & 17.72 & 31.58 & 14.70 \\
\hline \multicolumn{11}{|l|}{ Rangpur } \\
\hline Farm wage & 39.86 & 61.63 & 58.20 & 70.08 & 75.73 & 72.79 & 172.65 & 145.47 & 284.63 & 140.17 \\
\hline Industrial wage & 75.45 & 132.32 & 107 & 167.90 & 129 & 186.56 & 260 & 157.38 & 298 & 171.23 \\
\hline Construction wage & 104.81 & 163.10 & 124.09 & 152.92 & 218.54 & 214.13 & 343.61 & 235.84 & 462.06 & 231.45 \\
\hline Rice price & 11.86 & 18.26 & 11.21 & 13.50 & 14.90 & 14.83 & 26.74 & 16.78 & 29.69 & 13.82 \\
\hline \multicolumn{11}{|l|}{ Rajshahi } \\
\hline Farm wage & 33.96 & 52.56 & 50.70 & 61.68 & 67.96 & 65.32 & 152.45 & 101.03 & 258.90 & 127.42 \\
\hline Industrial wage & 75.45 & 132 & 107 & 167.90 & 129 & 186.56 & 260.41 & 157.58 & 299.91 & 170.10 \\
\hline Construction wage & 124.44 & 193.62 & 161.11 & 198.55 & 186.58 & 183.21 & 309.58 & 212.55 & 491.53 & 246.36 \\
\hline Rice price & 12.39 & 19.03 & 11.38 & 13.70 & 15.54 & 14.21 & 27.85 & 17.59 & 31.03 & 14.44 \\
\hline \multicolumn{11}{|l|}{ Khulna } \\
\hline Farm wage & 39.63 & 61.30 & 57.25 & 69.64 & 71.22 & 68.47 & 149.56 & 99.16 & 261.75 & 128.92 \\
\hline Industrial wage & 75.45 & 132 & 107 & & 129 & 186.56 & 263.91 & 157.55 & 309.83 & 173.19 \\
\hline Construction wage & 95.62 & 148.71 & 179 & 220.61 & 207.54 & 203.50 & 289.30 & 198.72 & 473.58 & 237.73 \\
\hline Rice price & 12.02 & 18.52 & 11.37 & 13.69 & 15.11 & 14.42 & 27.98 & 17.58 & 30.15 & 14.04 \\
\hline \multicolumn{11}{|l|}{ Sylhet } \\
\hline Farm wage & 49.5 & 76.56 & 68.92 & 83.84 & 92.08 & 88.49 & 172.25 & 114.38 & 302.58 & 149.04 \\
\hline Industrial wage & 75.45 & 132.24 & 107 & 167.90 & 129 & 186.56 & 256 & 157.29 & 320 & 173.19 \\
\hline Construction wage & 184.22 & 286.76 & 213.33 & 262.96 & 286.52 & 280.10 & 334.17 & 229.86 & 472.93 & 237.05 \\
\hline Rice price & 12.98 & 19.98 & 11.81 & 14.22 & 15.45 & 14.74 & 27.48 & 17.26 & 32.35 & 15.06 \\
\hline \multicolumn{11}{|l|}{ Barisal } \\
\hline Farm wage & 40.08 & 61.95 & 59.17 & 71.92 & 80.25 & 77.11 & 195.75 & 129.98 & 309.92 & 152.54 \\
\hline Industrial wage & 75.45 & & 107.80 & 167.79 & 129 & 167.90 & 263 & 157.55 & 320 & 180.38 \\
\hline Construction wage & 95.01 & 148.24 & 178 & 220.64 & 207.54 & 203.50 & 290 & 198.72 & 473.20 & 237.15 \\
\hline Rice price & 12.54 & 19.32 & 11.71 & 14.10 & 15.74 & 15.02 & 29.06 & 18.24 & 30.38 & 14.15 \\
\hline \multicolumn{11}{|l|}{ Chittagong } \\
\hline Farm wage & 55.10 & 85.22 & 73.42 & 89.32 & 100.57 & 96.69 & 197.80 & 131.14 & 339.28 & 167 \\
\hline Industrial wage & 75.45 & 132.25 & 107 & 167.90 & 129 & 186.56 & 263.25 & 157.29 & 331 & 180 \\
\hline Construction wage & 160.44 & 249.53 & 218 & 268.60 & 270.97 & 265.74 & 367.36 & 252.23 & 474.86 & 238.01 \\
\hline Rice price & 12.72 & 19.58 & 11.69 & 14.08 & 15.58 & 14.87 & 26.55 & 16.69 & 30.42 & 14.16 \\
\hline
\end{tabular}

Source: Authors' calculation based on monthly bulletins by the BBS and reports by the FPMU

Notes: Rural and urban consumer price indices were used to estimate real wages and prices; 1 USD = 77.37 BDT in December,2014

(Source:https://www.ecb.europa.eu/home/html/index.en.html)

change of direction in poverty after 2005. Dhaka experienced a large poverty decline despite a decline in the growth rate of real wages between 2000 and 2005. A large decline in headcount ratio (HCR) and a large increase in wages were 
observed in Chittagong between 2005 and 2010. While Barisal experienced a small rise in wages and a small decline in poverty during 2005 . Rajshahi experienced a small poverty decline although wages had fallen prior to 2010. Khulna experienced the second highest rise in wages and a decrease in poverty between 2000 and 2010, but the rate of poverty reduction slowed down between 2010 and 2015.

\section{Results}

\subsection{Unit root test, structural breaks and possible reasons for such breaks}

Before testing for the existence of a unit root in the time series and determining the order of integration, it is essential to determine any structural breaks in the relationship among the variables. For each division, we considered four variables, namely farm wages, urban construction wages, urban manufacturing wages, and rice prices. The entire period spans 21 years (or 252 months) from 1994 to 2014 . The structural breaks detected by the Supremum Wald test are listed in Table 2. In this test, we included all four variables. As we were more interested in the response of agricultural wages to changes in rice prices and urban wages, we examine the unknown structural break in which the farm wage is the dependent variable.

All structural breaks happened between January 2007 (in Khulna) and January 2009 (in Mymensingh). The detected structural breaks appear to be consistent with structural changes in Bangladesh's economy. The international financial crisis and recession in the international market took place in 2008 . At the same time, international rice prices peaked, followed by the rice export ban imposed by India, one of Bangladesh's major trading partners. As a response to the economic turmoil, the hundred-day employment generation program was implemented in 2009 to control short-term unemployment in a time where food prices were soaring. In addition, the period was also characterized by political instability. Between 2006 and

Table 2 Structural break in the different divisions

\begin{tabular}{ll}
\hline Division & Unknown Structural break \\
\hline Dhaka & $2009 \mathrm{M} 1$ \\
Mymensingh & $2009 \mathrm{M} 1$ \\
Rangpur & $2008 \mathrm{M} 12$ \\
Rajshahi & $2008 \mathrm{M} 12$ \\
Khulna & $2007 \mathrm{M} 1$ \\
Sylhet & $2008 \mathrm{M} 1$ \\
Barisal & $2008 \mathrm{M} 12$ \\
Chittagong & $2008 \mathrm{M} 12$ \\
\hline
\end{tabular}

2008, a caretaker government was in power before an elected government took over in 2009. Lastly, the minimum wage of garment workers was raised twice, once in 2006 and again in 2010. Against this background, the existence of a structural break during this period appears to be very reasonable. The correlation matrix of the explanatory variables in their first differences can be found in Technical Appendix 1.

We performed several standard test procedures, namely the Augmented Dickey-Fuller (ADF) test, the KwiatkowskiPhillips-Schmidt-Shin (KPSS) test and the modified DickeyFuller t-test (ADF-GLS). All of them are common methods to test for the presence of a regular unit root. The null hypothesis of the ADF and the ADF-GLS tests is that the data series is non-stationary. By contrast, the KPSS test tests the null hypothesis of stationarity. We omitted the detailed test statistics at different lags, which are available on request, and present the results in Tables 3 and 4. From the results, it is evident that all the $\log$ series exhibit a unit root. To verify the level of integration of the series, we again tested for a unit root for the differenced time series, which confirmed the existence of I (1) processes in the original series. In addition to that, we also tested for the presence of seasonal unit roots. The respective results are presented in Technical Appendix 2. Based on these results, we were able to reject the systematic existence of seasonal unit roots.

\subsection{Long-run relations among the series and speed of adjustment}

Based on the results of the structural break test above, we treated the periods before and after the structural break separately. The time series was tested for the existence of cointegrating equations by using trace statistics and eigenvalues. The detailed results of the lag length selection, based on the information criteria, and the Johansen contegration test procedure can be found in Hassan and Kornher (2019). Using the critical value of the 5\% level of significance as the criterion, we found one cointegrating vector for all the eight divisions before the structural break. Table 5 shows the respective VECM estimates for farm wages as the endogenous variable. The results of the estimated VECM parameters indicate that farm wages are integrated with the other series, as evidenced by the statistically significant error correction term and its negative sign. Before the break around 2008, farm wages among all the divisions had significant long-run relationships with the rice prices. The same holds true for urban wages since in each division one of the two urban wages was positively associated with farm wages, indicating a significant long-run relationship.

Similarly, after the break, the Johansen test statistics suggest one cointegration relationship for all divisions. By contrast, farm wages exhibited a significant long-run relationship with rice prices in only three divisions (Dhaka, Mymensingh, and Rajshahi). After the break, the long-run farm wages in all 
Table 3 Regular unit root test (data in level)

\begin{tabular}{|c|c|c|c|c|c|c|c|c|c|c|}
\hline Division & Unit Root Test & $\begin{array}{l}\mathrm{Ln} \mathrm{W}_{\mathrm{a}} \\
\text { Before }\end{array}$ & $\begin{array}{l}\operatorname{Ln} F_{p} \\
\text { eak }\end{array}$ & $\mathrm{Ln} \mathrm{W}_{\mathrm{m}}$ & $\operatorname{Ln} W_{c}$ & Break point & $\begin{array}{l}\mathrm{Ln} \mathrm{W}_{\mathrm{a}} \\
\text { After break }\end{array}$ & $\operatorname{Ln} F_{p}$ & Ln $W_{m}$ & $\operatorname{Ln} \mathrm{W}_{\mathrm{c}}$ \\
\hline \multirow[t]{3}{*}{ Dhaka } & $\mathrm{ADF}$ & $\begin{array}{l}2.481 \\
(0.11)\end{array}$ & $\begin{array}{l}2.583 \\
(0.10)\end{array}$ & $\begin{array}{l}0.914 \\
(0.78)\end{array}$ & $\begin{array}{l}2.482 \\
(0.16)\end{array}$ & \multirow[t]{3}{*}{2009 M1 } & $\begin{array}{l}0.28 \\
(.053)\end{array}$ & $\begin{array}{l}1.98 \\
(0.29)\end{array}$ & $\begin{array}{l}3.77 \\
(.043)\end{array}$ & $\begin{array}{l}0.31 \\
(0.16)\end{array}$ \\
\hline & $\begin{array}{l}\text { GLS } \\
\text { ADF }\end{array}$ & 3.18 & 2.76 & 0.173 & 0.216 & & 2.575 & 1.448 & 2.317 & 1.697 \\
\hline & KPSS & 0.459 & 1.000 & 0.442 & 1.350 & & 0.351 & 0.315 & 0.175 & 0.474 \\
\hline \multirow[t]{3}{*}{ Mymensingh } & $\mathrm{ADF}$ & $\begin{array}{l}3.209 \\
(0.06)\end{array}$ & $\begin{array}{l}2.801 \\
(0.07)\end{array}$ & $\begin{array}{l}1.833 \\
(0.36)\end{array}$ & $\begin{array}{l}2.312 \\
(0.16)\end{array}$ & \multirow[t]{3}{*}{2009 M1 } & $\begin{array}{l}3.209 \\
(0.02)\end{array}$ & $\begin{array}{l}2.002 \\
(0.28)\end{array}$ & $\begin{array}{l}1.605 \\
(0.48)\end{array}$ & $\begin{array}{l}2.363 \\
(0.15)\end{array}$ \\
\hline & GLS ADF & 3.33 & 3.30 & 1.674 & 2.08 & & 3.25 & 1.654 & 2.630 & 1.697 \\
\hline & KPSS & 0.462 & 0.914 & 0.412 & 1.35 & & 0.286 & 0.310 & 0.239 & 0.472 \\
\hline \multirow[t]{3}{*}{ Khulna } & $\mathrm{ADF}$ & $\begin{array}{l}3.62 \\
(0.06)\end{array}$ & $\begin{array}{l}2.668 \\
(0.07)\end{array}$ & $\begin{array}{l}1.663 \\
(0.45)\end{array}$ & $\begin{array}{l}2.452 \\
(0.12)\end{array}$ & \multirow[t]{3}{*}{2007 M1 } & $\begin{array}{l}1.867 \\
(0.34)\end{array}$ & $\begin{array}{l}1.493 \\
(0.53)\end{array}$ & $\begin{array}{l}3.065 \\
(0.05)\end{array}$ & $\begin{array}{l}2.291 \\
(0.17)\end{array}$ \\
\hline & GLS ADF & 1.507 & 3.30 & 1.674 & 2.08 & & 3.420 & 1.760 & 0.738 & 2.511 \\
\hline & KPSS & 0.564 & 0.547 & 0.731 & 1.59 & & 0.352 & 0.165 & 0.364 & 0.331 \\
\hline \multirow[t]{3}{*}{ Sylhet } & $\mathrm{ADF}$ & $\begin{array}{l}3.169 \\
(0.02)\end{array}$ & $\begin{array}{l}2.448 \\
(0.13)\end{array}$ & $\begin{array}{l}2.801 \\
(0.06)\end{array}$ & $\begin{array}{l}1.902 \\
(0.33)\end{array}$ & \multirow[t]{3}{*}{2008 M1 } & $\begin{array}{l}2.166 \\
(0.21)\end{array}$ & $\begin{array}{l}1.771 \\
(0.39)\end{array}$ & $\begin{array}{l}2.370 \\
(0.15)\end{array}$ & $\begin{array}{l}5.281 \\
(0.00)\end{array}$ \\
\hline & GLS ADF & 2.918 & 3.061 & 2.007 & 1.220 & & 3.40 & 1.823 & 1.674 & 1.495 \\
\hline & KPSS & 0.222 & 0.914 & 0.698 & 0.988 & & 0.218 & 0.184 & 0.166 & 0.375 \\
\hline \multirow[t]{3}{*}{ Rajshahi } & $\mathrm{ADF}$ & $\begin{array}{l}1.261 \\
(0.65)\end{array}$ & $\begin{array}{l}2.981 \\
(0.04)\end{array}$ & $\begin{array}{l}0.340 \\
(0.03)\end{array}$ & $\begin{array}{l}2.312 \\
(0.16)\end{array}$ & \multirow[t]{3}{*}{2008 M12 } & $\begin{array}{l}2.305 \\
(0.17)\end{array}$ & $\begin{array}{l}1.891 \\
(0.33)\end{array}$ & $\begin{array}{l}0.293 \\
(0.92)\end{array}$ & $\begin{array}{l}1.754 \\
(0.40)\end{array}$ \\
\hline & GLS ADF & 2.242 & 2.520 & 1.699 & 3.303 & & 2.636 & 2.365 & 2.201 & 1.590 \\
\hline & KPSS & 0.680 & 1.010 & 0.431 & .512 & & 0.546 & 0.267 & 0.325 & .455 \\
\hline \multirow[t]{3}{*}{ Rangpur } & $\mathrm{ADF}$ & $\begin{array}{l}0.679 \\
(0.85)\end{array}$ & $\begin{array}{l}3.082 \\
(0.02)\end{array}$ & $\begin{array}{l}0.857 \\
(0.80)\end{array}$ & $\begin{array}{l}2.619 \\
(0.08)\end{array}$ & \multirow[t]{3}{*}{2008 M12 } & $2.617(0.06)$ & $\begin{array}{l}1.980 \\
(0.07)\end{array}$ & $\begin{array}{l}0.808 \\
(0.36)\end{array}$ & $\begin{array}{l}3.561 \\
(0.00)\end{array}$ \\
\hline & GLS ADF & 1.604 & 2.638 & 1.824 & 2.857 & & 2.92 & 1.542 & 1.842 & 2.51 \\
\hline & KPSS & 0.764 & 1.02 & 0.45 & 0.41 & & 0.261 & 0.290 & 0.363 & 1.89 \\
\hline \multirow[t]{3}{*}{ Barisal } & $\mathrm{ADF}$ & $\begin{array}{l}0.457 \\
(0.90)\end{array}$ & $\begin{array}{l}0.893 \\
(0.79)\end{array}$ & $\begin{array}{l}0.893 \\
(0.02)\end{array}$ & $\begin{array}{l}2.858 \\
(0.06)\end{array}$ & \multirow[t]{3}{*}{2008 M12 } & $\begin{array}{l}4.347 \\
(0.04)\end{array}$ & $\begin{array}{l}1.616 \\
(0.47)\end{array}$ & $\begin{array}{l}0.293 \\
(0.92)\end{array}$ & $\begin{array}{l}1.667 \\
(0.44)\end{array}$ \\
\hline & GLS ADF & 1.631 & 2.84 & 1.699 & 1.532 & & 4.13 & 2.28 & 2.205 & 1.75 \\
\hline & KPSS & 0.826 & 0.833 & 0.431 & 1.76 & & 0.101 & 0.287 & .325 & .534 \\
\hline \multirow[t]{3}{*}{ Chittagong } & $\mathrm{ADF}$ & $\begin{array}{l}0.559 \\
(0.87)\end{array}$ & $\begin{array}{l}2.535 \\
(0.09)\end{array}$ & $\begin{array}{l}0.835 \\
(0.80)\end{array}$ & $\begin{array}{l}3.609 \\
(0.03)\end{array}$ & \multirow[t]{3}{*}{2008 M12 } & $\begin{array}{l}3.270 \\
(0.03)\end{array}$ & $\begin{array}{l}2.101 \\
(0.24)\end{array}$ & $\begin{array}{l}1.78 \\
(0.41)\end{array}$ & $\begin{array}{l}2.530 \\
(0.10)\end{array}$ \\
\hline & GLS ADF & 1.665 & 2.90 & 1.76 & 2.47 & & 2.943 & 2.113 & 2.481 & 2.767 \\
\hline & KPSS & 0.868 & 0.867 & 0.480 & 0.641 & & 0.107 & 0.307 & 0.193 & 0.245 \\
\hline
\end{tabular}

Note: Tests were conducted on natural log of real wage and real price series. $\mathrm{W}_{\mathrm{a}}, \mathrm{W}_{\mathrm{m}}, \mathrm{W}_{\mathrm{c}} \mathrm{F}_{\mathrm{p}}$ stand for agricultural, industrial, construction wages and food prices, respectively. Results are in absolute values. The ADF and KPSS critical values at the $5 \%$ level of significance are -3.07 and 0.463 , respectively. The critical value for the ADF test is taken from MacKinnon (1991). The GLS-ADF critical value at 5\% in lag 2 is 3.486. Parentheses represent $P$-values

divisions (except Barisal) were significantly influenced by urban wages. These results are in accordance with the findings of Rashid (2002), who projected more than a decade ago that the urban wage rate would become the most influential factor for farm wage determination. However, the relative effect of rice prices on farm wages is slowly diminishing over time despite the remarkable increase in rice production due to the advent of new drought draft- and salt-tolerant varieties. The increased rice price did not affect the poor in rural areas as the economic growth accelerated and poverty reduction became significant between 2000 and 2014. Any possible negative impacts of increased rice price on income only affected the people of Dhaka and. Such regional diversity in elasticities will be further discussed in the upcoming sections.

Table 5 also presents the speed of adjustment for any deviation from the long-run equilibrium. The error term coefficient represents the speed of adjustment. We expected a statistically significant and negative coefficient of the error correction term, which would indicate that the system converged back to its equilibrium relationship. The exact value of the coefficient tells us the portion of the correction happening during the period of adjustment. It is apparent from Table 5 (columns 6 and 13) that the models behaved as expected, as indicated by the negative sign and the statistically significant 
Table 4 Regular unit root test (1st differenced data)

\begin{tabular}{|c|c|c|c|c|c|c|c|c|c|c|}
\hline Division & Unit Root Test & $\begin{array}{l}\mathrm{Ln} \mathrm{W}_{\mathrm{a}} \\
\text { Before break }\end{array}$ & $\operatorname{Ln} F_{p}$ & $\mathrm{Ln} \mathrm{W}_{\mathrm{m}}$ & $\operatorname{Ln} W_{c}$ & Break point & $\begin{array}{l}\text { Ln } W_{a} \\
\text { After brea }\end{array}$ & $\operatorname{Ln}_{\mathrm{k}}$ & $\mathrm{Ln} \mathrm{W}_{\mathrm{m}}$ & $\mathrm{Ln} \mathrm{W}_{\mathrm{c}}$ \\
\hline \multirow[t]{3}{*}{ Dhaka } & $\mathrm{ADF}$ & $\begin{array}{l}16.29 \\
(0.00)\end{array}$ & $\begin{array}{l}11.95 \\
(0.00)\end{array}$ & $\begin{array}{l}13.72 \\
(0.00)\end{array}$ & $\begin{array}{l}2.31 \\
(0.16)\end{array}$ & 2009 M1 & $\begin{array}{l}10.34 \\
(0.00)\end{array}$ & $\begin{array}{l}7.721 \\
(.00)\end{array}$ & $\begin{array}{l}13.77 \\
(0.00)\end{array}$ & $\begin{array}{l}15.16 \\
(0.00)\end{array}$ \\
\hline & $\begin{array}{l}\text { GLS } \\
\text { ADF }\end{array}$ & 14.28 & 7.462 & 9.423 & 10.73 & & 9.847 & 3.578 & 9.674 & 5.288 \\
\hline & KPSS & 0.016 & 0.025 & 0.041 & 0.039 & & 0.016 & 0.101 & 0.022 & 0.038 \\
\hline \multirow[t]{3}{*}{ Mymensingh } & $\mathrm{ADF}$ & $\begin{array}{l}18.01 \\
(0.00)\end{array}$ & $\begin{array}{l}11.21 \\
(0.00)\end{array}$ & $17.60(0.00)$ & $\begin{array}{l}15.16 \\
(0.00)\end{array}$ & 2009 M1 & $\begin{array}{l}10.69 \\
(0.00)\end{array}$ & $\begin{array}{l}6.829 \\
(0.00)\end{array}$ & $\begin{array}{l}6.792 \\
(0.00)\end{array}$ & $\begin{array}{l}9.534 \\
(0.00)\end{array}$ \\
\hline & GLS ADF & 13.11 & 7.308 & 9.48 & 10.37 & & 9.391 & 4.341 & 4.615 & 5.281 \\
\hline & KPSS & 0.011 & 0.020 & 0.047 & 0.039 & & 0.286 & 0.310 & 0.239 & 0.472 \\
\hline \multirow[t]{3}{*}{ Khulna } & $\mathrm{ADF}$ & $\begin{array}{l}17.51 \\
(0.00)\end{array}$ & $\begin{array}{l}11.95 \\
(0.00)\end{array}$ & $\begin{array}{l}11.75 \\
(0.00)\end{array}$ & $\begin{array}{l}18.94 \\
(0.00)\end{array}$ & 2007 M1 & $\begin{array}{l}11.57 \\
(0.00)\end{array}$ & $\begin{array}{l}8.775 \\
(0.00)\end{array}$ & $\begin{array}{l}9.811 \\
(0.00)\end{array}$ & $\begin{array}{l}13.84 \\
(0.00)\end{array}$ \\
\hline & GLS ADF & 12.41 & 6.550 & 7.615 & 15.10 & & 9.268 & 5.020 & 3.745 & 6.271 \\
\hline & KPSS & 0.018 & 0.028 & 0.068 & 0.031 & & 0.020 & 0.089 & 0.066 & 0.038 \\
\hline \multirow[t]{3}{*}{ Sylhet } & $\mathrm{ADF}$ & $\begin{array}{l}18.50 \\
(0.00)\end{array}$ & $\begin{array}{l}13.05 \\
(0.00)\end{array}$ & $\begin{array}{l}17.04 \\
(0.00)\end{array}$ & $\begin{array}{l}15.74 \\
(0.00)\end{array}$ & $2008 \mathrm{M} 1$ & $\begin{array}{l}9.913 \\
(0.00)\end{array}$ & $\begin{array}{l}9.221 \\
(0.00)\end{array}$ & $\begin{array}{l}7.789 \\
(0.00)\end{array}$ & $\begin{array}{l}17.40 \\
(0.00)\end{array}$ \\
\hline & GLS ADF & 8.128 & 4.723 & 9.108 & 12.51 & & 8.963 & 3.421 & 4.861 & 9.121 \\
\hline & KPSS & 0.012 & 0.061 & 0.058 & 0.043 & & 0.017 & 0.076 & 0.036 & 0.039 \\
\hline \multirow[t]{3}{*}{ Rajshahi } & $\mathrm{ADF}$ & $16.67(0.00)$ & $\begin{array}{l}15.03 \\
(0.00)\end{array}$ & $\begin{array}{l}13.62 \\
(0.00)\end{array}$ & $\begin{array}{l}16.54 \\
(0.00)\end{array}$ & 2008 M12 & $\begin{array}{l}12.47 \\
(0.17)\end{array}$ & $\begin{array}{l}8.84 \\
(0.33)\end{array}$ & $\begin{array}{l}8.254 \\
(0.92)\end{array}$ & $\begin{array}{l}9.809 \\
(0.40)\end{array}$ \\
\hline & GLS ADF & 11.45 & 7.420 & 8.450 & 12.58 & & 7.714 & 4.221 & 6.371 & 6.201 \\
\hline & KPSS & 0.030 & 0.021 & 0.051 & 0.027 & & 0.028 & 0.097 & 0.039 & 0.076 \\
\hline \multirow[t]{3}{*}{ Rangpur } & $\mathrm{ADF}$ & $\begin{array}{l}17.62 \\
(0.00)\end{array}$ & $\begin{array}{l}15.03 \\
(0.00)\end{array}$ & $\begin{array}{l}12.92 \\
(0.00)\end{array}$ & $\begin{array}{l}16.21 \\
(0.00)\end{array}$ & 2008 M12 & $\begin{array}{l}11.92 \\
(0.00)\end{array}$ & $\begin{array}{l}9.789 \\
(0.00)\end{array}$ & $\begin{array}{l}8.490 \\
(0.00)\end{array}$ & $\begin{array}{l}12.92 \\
(0.00)\end{array}$ \\
\hline & GLS ADF & 4.970 & 7.481 & 9.511 & 11.01 & & 7.790 & 4.021 & 5.061 & 9.04 \\
\hline & KPSS & 0.043 & 0.023 & 0.048 & 0.021 & & 0.018 & 0.095 & 0.048 & 0.028 \\
\hline \multirow[t]{3}{*}{ Barisal } & $\mathrm{ADF}$ & $\begin{array}{l}14.15 \\
(0.00)\end{array}$ & $\begin{array}{l}17.15 \\
(0.00)\end{array}$ & $\begin{array}{l}13.69 \\
(0.00)\end{array}$ & $\begin{array}{l}21.54 \\
(0.00)\end{array}$ & 2008 M12 & $\begin{array}{l}14.19 \\
(0.00)\end{array}$ & $\begin{array}{l}8.705 \\
(0.00)\end{array}$ & $\begin{array}{l}8.230 \\
(0.00)\end{array}$ & $\begin{array}{l}8.980 \\
(0.00)\end{array}$ \\
\hline & GLS ADF & 9.082 & 7.720 & 8.453 & 14.15 & & 7.13 & 4.705 & 6.37 & 4.35 \\
\hline & KPSS & 0.035 & 0.017 & 0.052 & 0.033 & & 0.017 & 0.097 & 0.03 & 0.08 \\
\hline \multirow[t]{3}{*}{ Chittagong } & $\mathrm{ADF}$ & $\begin{array}{l}17.12 \\
(0.00)\end{array}$ & $\begin{array}{l}12.43 \\
(0.00)\end{array}$ & $\begin{array}{l}13.10 \\
(0.00)\end{array}$ & $\begin{array}{l}20.40 \\
(0.00)\end{array}$ & 2008 M12 & $\begin{array}{l}14.19 \\
(0.00)\end{array}$ & $\begin{array}{l}8.248 \\
(0.00)\end{array}$ & $\begin{array}{l}8.769 \\
(0.00)\end{array}$ & $\begin{array}{l}9.704 \\
(0.00)\end{array}$ \\
\hline & GLS ADF & 3.820 & 5.220 & 8.865 & 13.74 & & 7.134 & 4.118 & 5.115 & 6.051 \\
\hline & KPSS & .0365 & 0.026 & 0.048 & 0.016 & & 0.017 & 0.079 & 0.034 & 0.035 \\
\hline
\end{tabular}

Note: Tests were conducted on natural log of real wage and real price series. $\mathrm{W}_{\mathrm{a}}, \mathrm{W}_{\mathrm{m}}, \mathrm{W}_{\mathrm{c}}$, and $\mathrm{F}_{\mathrm{p}}$ stand for agricultural, industrial, construction wages, and food prices, respectively. Results are in absolute values. The ADF and KPSS critical values at the 5\% level of significance are -3.07 and 0.463 , respectively. The critical value for the ADF test is taken from MacKinnon (1991). The GLS-ADF critical value at 5\% in lag 2 is 3.486. Parentheses represent P-values

coefficient (at the $1 \%$ level of significance) of the error correction term for both periods. These results also show that the models considering farm wages on the left-hand side of the cointegration equation were well specified. For instance, before the structural break, we found quick adjustment periods for Mymensingh (20 months), Sylhet (22 months), and Dhaka (23 months). Intuitively, this implies that in Mymensingh, it took 20 months to retain the long-run equilibrium condition, while in each month the error correction term corrected the previous period's disequilibrium at a speed of $58.2 \%$ to reach the steady-state level. By contrast, the adjustment was rather sluggish in Barisal (88 months) and Chittagong (68 months).
After the break, Barisal exhibited the shortest adjustment period (14 months), while Khulna had the longest adjustment period (55 months). All the models were checked and diagnosed for the stable coefficients of the estimated parameters (Technical Appendix 3).

\subsection{Rice price pass-through coefficients}

In order to better understand the transmission of changes of rice prices and urban wages to farm wages, we also computed pass-through coefficients. The magnitude of the rice price passes through on-farm wages and allows us to explicitly test 


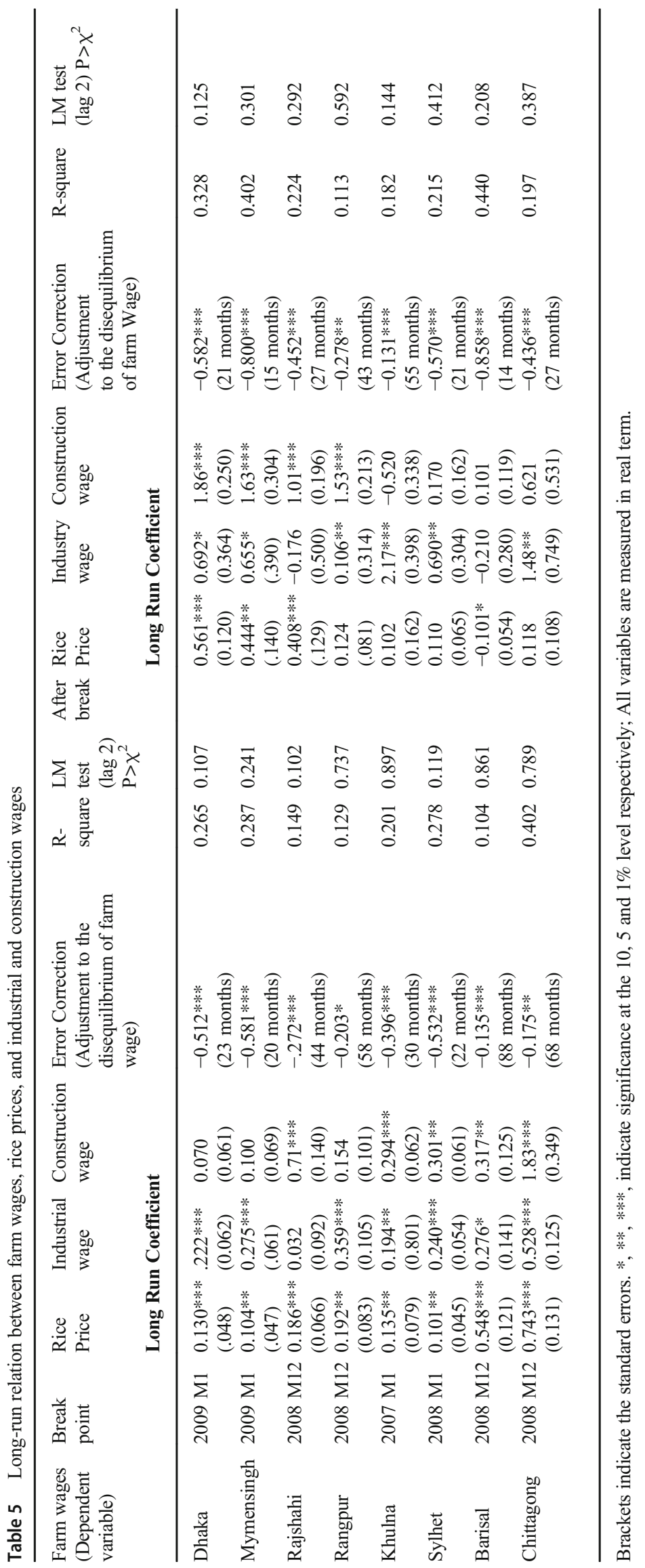


the sticky wages theory of Keynes. The pass-through coefficients, computed using Eq. (3) for different time horizons, are shown in Table 6 . We found that the pass-through coefficients vary across divisions and over time, specifically before and after the break. We found significant pass-through in Dhaka and Sylhet before the break and in Mymensingh after the break for the three months' time horizon. Six out of eight divisions exhibited a significant pass-through after six months in the period before the structural break, but all of them became insignificant after the structural break. Only half of the divisions, namely Rajshahi, Rangpur, Sylhet, and Chittagong, are estimated to have significant passthrough elasticities before the break for the twelve months' time horizon. With regard to the 12-month pass-through, except for Barisal, we did not find any significant pass-through after the break. The findings of transmission analysis emphasize the need to monitor the rice price pass through in critical periods and the estimated elasticities could be used in quick policy plan to detect divisions where significant changes in rice price will have adverse implications for the vulnerable population. Thus being said, a more detailed examination of the differential degree of price transmission need to include further explanatory variables like transportation costs, trade, GDP, or grains stocks.

Hence, it is clear that the importance of rice prices in the determination of farm wages significantly declined after the structural break in 2008/2009. Moreover, all pass-through coefficients were below 0.4 , which indicates that the price elasticity of wages in Bangladesh was not close to unity, even for relatively long time horizons. These pass-through effects nullify the assumption of a one-to-one relationship between staple food prices and farm wages (Ravallion, 2006; Martin \& Ivanic, 2016). The picture for the urban wage passthrough is somewhat different. The details are shown in Technical Appendix 4. Generally, the amount of significant pass-through coefficients is limited. Yet, once the pass-through coefficients became significant, the magnitude was much higher for urban wages than for rice prices.

\subsection{Regional differences}

In general, we observed a common trend for all divisions which indicates that the importance of rice prices for farm wage determination declined over time, while urban wages in the construction and industrial sectors remained important. However, we also found regional differences. Before the break, farm wages were more responsive to rice price changes in both Chittagong and Barisal than in the other divisions. To be more precise, the magnitude of the rice-price coefficient varied greatly between 0.743 in Chittagong and 0.111 in Sylhet (Table 5). Generally, geographically close and neighboring divisions exhibit similar patterns; for instance Chittangon and Barisal as well as Dhaka and Mymensingh. There are several factors that might have influenced such variability, including demographic characteristics, the volume of rice production, the number of agricultural households, the cropping intensity, labor migration issues, and the adoption of onfarm machinery as well as the overall poverty situation. Table 7 summarizes long-run, short-run elasticities, and labor demand at a glance.

A more detailed discussion of the cross-division differences would require further analysis, including the

Table 6 Real farm wage response to real rice prices

\begin{tabular}{|c|c|c|c|c|c|c|}
\hline & \multicolumn{2}{|c|}{ Three months pass-through coefficients } & \multicolumn{2}{|c|}{ Six months pass-through coefficients } & \multicolumn{2}{|c|}{ Twelve months pass-through coefficients } \\
\hline & Before Break (2008) & After Break (2008) & Before Break & After Break & Before Break & After break \\
\hline Dhaka & $.163 * * *$ & .102 & $.216 * * *$ & -.044 & .113 & -.058 \\
\hline Mymensingh & .055 & $.395 * *$ & .121 & .191 & .071 & .100 \\
\hline Rajshahi & .037 & .091 & $.169 * * *$ & .215 & $.238 * *$ & .307 \\
\hline Rangpur & -.019 & -.053 & $.106^{*}$ & -.034 & $.216 * *$ & -.066 \\
\hline Sylhet & $.084 *$ & .186 & $.119 * *$ & .297 & $.178 *$ & -.004 \\
\hline Khulna & .030 & .066 & $.112 *$ & .050 & .178 & .156 \\
\hline Barisal & .002 & -.0506 & .095 & -.083 & .116 & $-.140 *$ \\
\hline Chittagong & .013 & -.132 & $.127 * *$ & -.017 & $.239 *$ & -.327 \\
\hline
\end{tabular}

Note: Significant pass-through coefficients indicates by bolding and *,**,***, indicate significance at the 10,5 and $1 \%$ level respectively 
utilization of additional counterfactuals, and is beyond the scope of the present study.

We also observed some changing trends of wage-price elasticities in the northern areas following the break, for example, in Rajshahi and Rangpur. The two divisions are traditionally rice-producing regions where many peoples are involved in agricultural activities, compared to other divisions (Khandker \& Samad, 2016). From Table 7, it is evident that a large portion of the rice cultivation in the country belongs to the Rajshahi and Rangpur divisions and at the same time a major fraction of the rural labor force of these areas are involved in selling their labor (Khandker \& Samad, 2016). In these divisions, rice prices had been very important for farm wage determination in the absence of non-farm employment opportunities. However, with the structural transformation of the economy, the effects of rice prices became less pronounced compared to construction and industrial urban wages. This is of particular importance in Rangpur, where seasonal famines (called "Monga"), which were partly due to the lack of lean season farm activities, became less frequent. In contrast to those two divisions, a $10 \%$ increase in rice price increased farm wages in Dhaka and Mymensingh by $1.9 \%$ and $4.4 \%$, respectively. In all the other divisions, wages did not respond to rice prices. In Barisal, we found that rice prices and wages were negatively correlated after the structural break. This is counterintuitive but could be explained by the incidence of a natural disaster, the cyclone Aila in 2009. Barisal is prone to natural disasters like cyclones due to its proximity to the sea and its multiple river deltas. After the 2009 cyclone, agricultural productivity decreased dramatically due to the influx of salt water into the rice fields, while rice prices increased due to low supply levels. Whenever employment opportunities decrease, disaster-related migration decouples labor and product markets. In the provinces of the largest commercial centers Dhaka and Chittagong, industrial wages are the driving force for rural agricultural wages following the structural break, while construction wages are not important in explaining changes in farm wages. This may be due to the importance of the garment industry in these divisions, which attracts rural workers to urban centers.

\section{Conclusion and scope of further research}

Farm wages and food prices are major determinants of rural livelihoods in Bangladesh. Rising food prices during the end of the 2000s have created additional threats to poverty reduction and rural welfare, although increasing food prices have also generated opportunities for net sellers of the respective commodity. The main objective of this study is to examine the drivers of farm wage formation and to increase the understanding of its implications for rural welfare. In this regard, it is also important to take into account the ongoing structural transformation of Bangladesh's economy towards manufacturing and services, including having one of the world's largest garment industries and a booming construction service. It is believed that the increase in agricultural prices has led to higher farm wages. In addition, services related to overseas employment and remittances have also shown a

Table 7 Summary of long- and short-run elasticities and labor demand

\begin{tabular}{|c|c|c|c|c|c|c|c|c|c|c|c|}
\hline \multirow{2}{*}{$\begin{array}{l}\text { Magnitude } \\
\text { Divisions }\end{array}$} & \multicolumn{7}{|c|}{ Long-run elasticities of real farm wages } & \multicolumn{3}{|c|}{$\begin{array}{l}\text { Pass-through (2008-2014) } \\
\text { elasticities in the short run }\end{array}$} & \multirow{2}{*}{$\begin{array}{l}\begin{array}{l}\text { Labor } \\
\text { demand }\end{array} \\
\begin{array}{c}\text { Cultivated } \\
\text { area }\end{array}\end{array}$} \\
\hline & Rice & Industry & Construction & Break & Rice & Industry & Construction & Rice & Industry & Construction & \\
\hline Dhaka & +++ & ++++ & + & & ++++++ & ++ & + & & $\mathrm{x}$ & $\mathrm{x}$ & $* * * * *$ \\
\hline Mymensingh & + & +++++++ & ++ & & +++++++ & +++++ & ++++++ & $\mathrm{x}$ & & $\mathrm{x}$ & $* * * *$ \\
\hline Rajshahi & ++++++ & + & ++++++ & & +++++++ & ++++ & ++++ & & $\mathrm{x}$ & & $* * * * * * * *$ \\
\hline Rangpur & +++++ & ++ & +++++ & & ++ & + & ++++++ & & & & $* * * * * * *$ \\
\hline Khulna & ++++ & ++ & ++ & & + & +++++++ & ++++ & & $\mathrm{x}$ & $\mathrm{x}$ & $* * *$ \\
\hline Sylhet & ++ & +++++ & +++ & & ++++ & ++++++ & +++ & & & & $*$ \\
\hline Barisal & +++++++ & ++++++ & +++++ & & +++ & +++ & ++ & $\mathrm{x}$ & & & $* *$ \\
\hline Chittagong & ++++++++ & ++++++++ & ++++++++ & & +++++ & ++++++++ & ++++++++ & & & & $* * * * * *$ \\
\hline
\end{tabular}

Note: "+" signs are arranged in ascending order of the size of the coefficient (bold sign means significance either at 1\%, $5 \%$, or $10 \%$ level of significance); " $x$ " indicates significant transmission of the price changes to real farm wage; The frequency of "**" indicates the demand for labor assuming that the more the area of rice cultivation in Aman and Boro seasons the more demand for labor 
drastic increase creating domestric employmen opportunities. Higher farm wages have general welfare effects, like increasing the agricultural income of workers, but they also lower income from fixed capital resources, such as land, due to increasing costs of labor (Jacoby, 2016). To measure such effects and to ascertain the welfare implications of changing food wages, an estimate of the relevant wage-price elasticities is required. In this study, we applied standard time series econometrics to analyze how the agricultural wage rate responds to changes in rice prices and urban wages. In addition, we tested for the stability of these relationships over time. In this way, we formally verified the Lewis turning point, after which the farm wage formation changes. Before the turning point, agricultural wages are merely determined at the subsistence level. Afterwards, labor supply becomes elastic, and prices increase when labor migrates into the other sectors of the economy.

We found strong empirical evidence for a structural break in the labor-food market relationship in the period between 2007 and 2008. This change might be associated with the adoption of labor-saving technologies in agriculture and the subsequent higher labor productivity as the results of the structural transformation of the economy. In addition, such changes in farm wages led to increased linkages between rural and urban labor markets. Although the structural break was observed for all eight divisions of the country, we found substantial differences in labor-food market integrations across all them. For instance, after the structural break around 2008, rice prices were significantly correlated with farm wages only in Dhaka, Rajshahi, and Mymensingh. Farm wages in all other divisions were influenced by either industrial or construction wages, but not by rice prices. These findings suggest strong evidence in favor of the Lewis turning point.

But if rice prices have little influence on the agricultural wage rate, then an increase in the price of rice will have little effect on wage rates, and will thus not lead to improvement in rural livelihoods and poverty reduction. The transmission of urban wage rate growth to agricultural labor markets benefits the income of rural farm laborers in the short-run, but also inflates the production cost of rice. To ensure food security, policymakers need to guarantee that rising production costs of rice are accompanied by increases in labor productivity. Agricultural mechanization, previously considered to be associated with the risk of labor substitution, could be promoted to compensate for a decreasing agricultural labor force and to enhance agricultural production. Alternatively, government policy could aim to control rice price movements through the national rice price stabilization scheme and other social programs such as vulnerable group development (VGD), vulnerable group feeding (VGF), Open Market Sales (OMS) and food for work (FFW) to maintain the balance between labor income and rice prices. In 2010, on average, two million households were eligible to receive fair price cards, which allow them to purchase $20 \mathrm{~kg}$ of rice per month at a reduced price (Alam \& Begum, 2014).To avoid large fiscal interventions, targeted programs should be preferred, such as the 2016 initiative to distribute rice to the ultra-poor at $10 \mathrm{BDT} / \mathrm{kg}$ and the fair price card program.

Nonetheless, the growth in the non-agricultural sector is the real driver of rural agricultural wages. Rising demand for labor due to growing industries in urban areas (the garment and construction sectors) has significantly driven up farm wages, which also has major implications for long-term poverty reduction. At present, farm workers are no longer in abundant supply. Such a transformation of the economy calls for a reorientation of agricultural policies. Therefore, more importance needs to be placed on non-farm employment opportunities, especially in the five divisions (excluding Dhaka, Mymensingh, and Rajshahi) where farm wages do not respond to increasing rice prices, to raise the purchasing power of agricultural laborers in the long run. Policy programs, such as the employment generation program for the poor (EGPP), could be a viable means; however, evaluating different policy options goes beyond the scope of this work. Moreover, any other policy aimed at enhancing farm labor income by increasing domestic rice prices (e.g., import tax) needs to be evaluated in view of limited transmission of rice price changes to farm wages in both the short term and the long term.

The results of the present study provide a better understanding of the welfare effects of staple food price changes on rural agricultural laborers. The effects need to be addressed by policymaking. Apart from rice prices and urban wages, rural labor markets are determined by several other economic factors, such as labor productivity, remittances, price stabilization policies, weather conditions, and general economic shocks. Since we are mainly interested in the price-wage nexus, we opted for the cointegration framework, which makes it difficult to include further endogenous variables, partly due to their mixed frequency nature. The inclusion of such variables in the time series model might, however, help to improve the understanding of the causal relationship between the variables and should be subject of future research. 


\section{Technical Appendix 1: Correlation matrix \\ of the explanatory variables}

Table 8 Correlation matrix of the explanatory variables

\begin{tabular}{|c|c|c|c|c|}
\hline Divisions & & Rice price & Industrial wage & Construction wage \\
\hline \multirow[t]{3}{*}{ Dhaka } & Rice price & 1 & & \\
\hline & Industrial wage & 0.0466 & 1 & \\
\hline & Construction wage & 0.0838 & 0.2366 & 1 \\
\hline \multirow[t]{3}{*}{ Mymensingh } & Rice price & 1 & & \\
\hline & Industrial wage & 0.0307 & 1 & \\
\hline & Construction wage & 0.1078 & 0.0188 & 1 \\
\hline \multirow[t]{3}{*}{ Rajshahi } & Rice price & 1 & & \\
\hline & Industrial wage & 0.0257 & 1 & \\
\hline & Construction wage & -0.0596 & 0.2162 & 1 \\
\hline \multirow[t]{3}{*}{ Rangpur } & Rice price & 1 & & \\
\hline & Industrial wage & -0.0116 & 1 & \\
\hline & Construction wage & 0.0614 & 0.0022 & 1 \\
\hline \multirow[t]{3}{*}{ Khulna } & Rice price & 1 & & \\
\hline & Industrial wage & 0.0173 & 1 & \\
\hline & Construction wage & 0.0173 & 0.2226 & 1 \\
\hline \multirow[t]{3}{*}{ Sylhet } & Rice price & 1 & & \\
\hline & Industrial wage & 0.0338 & 1 & \\
\hline & Construction wage & 0.0077 & 0.0154 & 1 \\
\hline \multirow[t]{3}{*}{ Barisal } & Rice price & 1 & & \\
\hline & Industrial wage & 0.0553 & 1 & \\
\hline & Construction wage & 0.0533 & 0.2366 & 1 \\
\hline \multirow[t]{3}{*}{ Chittagong } & Rice price & 1 & & \\
\hline & Industrial wage & 0.0727 & 1 & \\
\hline & Construction wage & 0.0802 & 0.4015 & 1 \\
\hline
\end{tabular}

\section{Technical Appendix 2: Seasonality and unit root of the respected series}

Sometimes both seasonal unit roots and seasonal heterogeneity are common in time series data. The HEGY (Hylleberg,
Engle, Granger, \& Yoo, 1990) test is a common tool for detecting seasonal unit roots. For all the series, considering the structural break, we checked for the possibility of a regular unit root along with the seasonal unit root test. The results are displayed in the following table.
Table 9 HEGY test of regular and seasonal unit roots

\begin{tabular}{llllll}
\hline Division & Stages of unit root & $\begin{array}{l}\text { Farm } \\
\text { wage }\end{array}$ & $\begin{array}{l}\text { Food } \\
\text { price }\end{array}$ & $\begin{array}{l}\text { Industrial } \\
\text { wage }\end{array}$ & $\begin{array}{l}\text { Construction } \\
\text { wage }\end{array}$ \\
\hline Dhaka & $\begin{array}{c}\text { Zero frequency } \\
\text { (non-seasonal) }\end{array}$ & yes & Yes & yes & Yes \\
Khulna & 4 months per cycle & No & No & No & No \\
Sylhet & 2.4 months per cycle & No & No & No & No \\
Rajshahi & 12 months per cycle & No & No & No & No \\
Rangpur & 3 months per cycle & No & No & No & No \\
Chittagong & 6 months per cycle & No & No & No & No \\
\hline
\end{tabular}




\section{Technical Appendix 3: Stability test}

Post-estimation of the VECM model requires checking whether the co-integrating equations are stationary. This process requires computing the eigenvalues of the companion matrix and counting the number of unit moduli in the whole system. If the number of unit moduli $(k)$ is less than the number of endogenous $(T)$ variables after subtracting the number of co-integrating vectors $(r)$, that means $k<T-r$, then the co- integration equation is stationary. Also, the Lagrange multiplier (LM) test for autocorrelation provides evidence of whether the residuals of the VECMs are autocorrelated or not. The Wald and Lagrange multiplier test found no autocorrelation of the residuals at the selected lags. The normality of the residuals was also examined. However, one minor limitation of the models is that they passed the examination of the stationarity and autocorrelation but marginally failed to form a normal distribution of the residuals.

\section{Technical Appendix 4: Price transmission in the short run}

Table 10 Real farm wage response to real industrial wages

\begin{tabular}{|c|c|c|c|c|c|c|}
\hline \multirow[t]{2}{*}{ Division } & \multicolumn{2}{|c|}{$\begin{array}{l}\text { Three-month pass-through } \\
\text { coefficients }\end{array}$} & \multicolumn{2}{|c|}{$\begin{array}{l}\text { Six-month pass-through co- } \\
\text { efficients }\end{array}$} & \multicolumn{2}{|c|}{$\begin{array}{l}\text { Twelve-month pass-through } \\
\text { coefficients }\end{array}$} \\
\hline & Before Break & After break & Before Break & After break & Before Break & After break \\
\hline Dhaka & -0.083 & $0.548 * *$ & 0.030 & 0.599 & 0.033 & -0.010 \\
\hline Mymensingh & -0.025 & $0.855^{* *} *$ & 0.048 & $1.11 * *$ & 0.024 & 0.510 \\
\hline Rajshahi & 0.001 & 0.222 & 0.155 & 0.231 & 0.212 & 0.399 \\
\hline Rangpur & 0.071 & 0.072 & 0.057 & 0.011 & 0.0901 & -0.30 \\
\hline Sylhet & -0.032 & 0.291 & 0.157 & 0.242 & 0.2574 & -0.32 \\
\hline Khulna & 0.009 & -0.219 & 0.081 & -0.23 & 0.089 & $-0.90 * *$ \\
\hline Barisal & -0.113 & 0.373 & -0.155 & 0.282 & -0.353 & 0.129 \\
\hline Chittagong & 0.085 & 0.126 & -0.179 & 0.320 & 0.249 & -1.0 \\
\hline
\end{tabular}

Note: Significant pass-through coefficients indicates by bolding and *,**, ***, indicate significance at the 10,5 and $1 \%$ level respectively

\begin{tabular}{|c|c|c|c|c|c|c|}
\hline \multirow[t]{2}{*}{ Division } & \multicolumn{2}{|c|}{$\begin{array}{l}\text { Three-month pass-through } \\
\text { coefficients }\end{array}$} & \multicolumn{2}{|c|}{$\begin{array}{l}\text { Six-month pass-through co- } \\
\text { efficients }\end{array}$} & \multicolumn{2}{|c|}{$\begin{array}{l}\text { Twelve-month pass-through } \\
\text { coefficients }\end{array}$} \\
\hline & Before Break & After break & Before Break & After break & Before Break & After break \\
\hline Dhaka & 0.063 & $0.766^{* * *}$ & 0.082 & 0.112 & 0.061 & -0.011 \\
\hline Mymensingh & 0.125 & 0.697 & 0.141 & 1.18 & 0.108 & 0.381 \\
\hline Rajshahi & 0.0859 & $0.949 * *$ & 0.069 & -0.202 & 0.112 & -0.638 \\
\hline Rangpur & -0.033 & 0.317 & 0.0791 & -0.683 & 0.175 & -0.282 \\
\hline Sylhet & 0.0339 & -0.034 & 0.039 & 0.4842 & 0.107 & 0.796 \\
\hline Khulna & 0.003 & 0.463 & 0.097 & 0.2582 & 0.138 & $1.27 * *$ \\
\hline Barisal & -0.003 & 0.242 & 0.138 & -0.54 & $0.234 *$ & -0.813 \\
\hline Chittagong & -.021 & 0.630 & $0.169 *$ & -0.136 & $0.313^{* * *}$ & -1.92 \\
\hline
\end{tabular}

Note: Significant pass-through coefficients indicates by bolding and $*, * *, * * *$, indicate significance at the 10,5 and $1 \%$ level respectively 


\section{Technical Appendix 5: Variability of key}

economic indicators

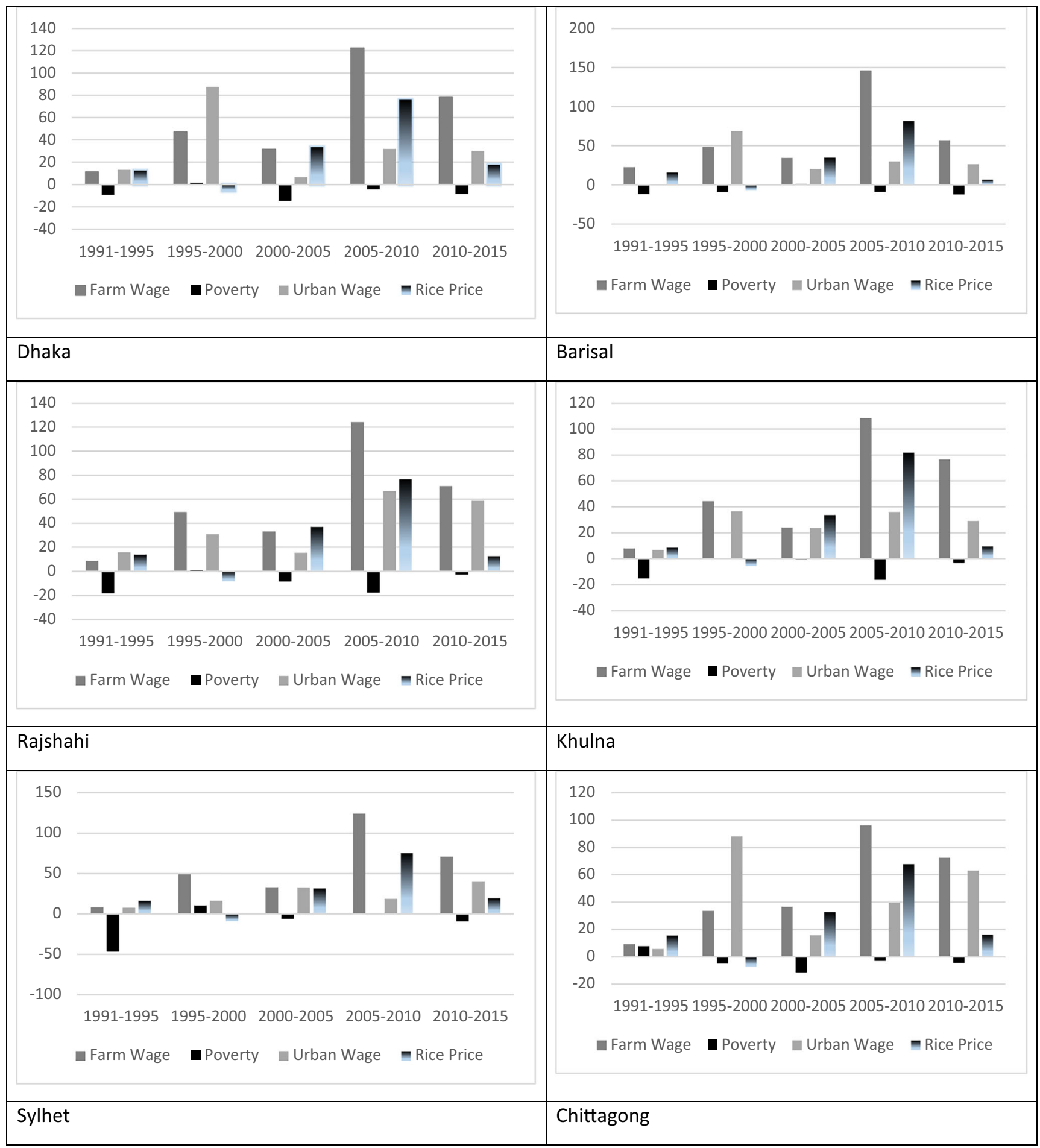

Fig. 4 Percentage change of wages, prices and poverty; source: HIES from (1991 to 2015) 
Acknowledgements The authors would like to acknowledge Prof. Dr. Dr. h.c. Joachim von Braun for his guidance during the development of this study; Dr. Mekbib G Haile, Dr. Sajjad Zohir, and Naser Farid for discussing the data collection sources and tools. The authors also acknowledge the anonymous reviewers for their work. Funding from the BMZ, DAAD, and the Foundation Fiat Panis is gratefully acknowledged.

Availability of data and materials The datasets used and/or analyzed during the current study are available from the corresponding author on reasonable request.

Code availability Statistical program code will be available upon request.

Authors' contributions FH conceptualized the work, reviewed the literature, and analyzed the data under supervision of LK. FH wrote the first draft and LK commented on the draft, modified technical aspects and contributed to the discussion of results. All authors read and approved the final manuscript.

Funding Open Access funding enabled and organized by Projekt DEAL. All costs of data collection for the study were covered by German Academic Exchange Service (DAAD) and Foundation Fiat Panis. The work of the authors was financed by the Federal Ministry of Economic Cooperation and Development of Germany (Research Project.

on Commodity Price Volatility, Trade Policy and the Poor) under the Grant Number 201195908.

Declaration We declare that this article is our original work and all the resources of material used for the article have been dually acknowledged.

Competing interests The authors declare that they have no competing interests.

Open Access This article is licensed under a Creative Commons Attribution 4.0 International License, which permits use, sharing, adaptation, distribution and reproduction in any medium or format, as long as you give appropriate credit to the original author(s) and the source, provide a link to the Creative Commons licence, and indicate if changes were made. The images or other third party material in this article are included in the article's Creative Commons licence, unless indicated otherwise in a credit line to the material. If material is not included in the article's Creative Commons licence and your intended use is not permitted by statutory regulation or exceeds the permitted use, you will need to obtain permission directly from the copyright holder. To view a copy of this licence, visit http://creativecommons.org/licenses/by/4.0/.

\section{References}

Adnan, T. (2018). Low wage crisis: Impacts on Bangladeshi garment sector workers. Journal of Mass Communication \& Journalism, 08(01), 8-11. https://doi.org/10.4172/2165-7912.1000357.

Ahmed R. (1999). Liberalization of Agricultural Input Markets in Bangladesh. In: Sidhu S.S., Mudahar M.S. (eds) Privatization and Deregulation. Springer, Dordrecht. https://doi.org/10.1007/978-94011-4583-1 16.

Akhter, S. (2017). Market integration between surplus and deficit rice markets during global food crisis period. Australian Journal of Agricultural and Resource Economics, 61(1), 172-188. https://doi. org/10.1111/1467-8489.12150.
Alam, M. J. \& Begum, I. A. (2014). Bangladesh's Rice Procurement System and Possible Alternatives in Supporting Farmer's Income and Sustaining Production Incentives. Retrieved from http://fpmu. gov.bd/agridrupal/sites/default/files/Bangladesh'sRiceprocurement. Pdf.

Barahona, J. F., \& Chulaphan, W. (2017). Price transmission between world food prices and different consumer food price indices in Thailand. Kasetsart Journal of Social Sciences XXX, 1-7. https:// doi.org/10.1016/j.kjss.2017.07.008.

BBS. (Bangladesh Bureau of Statistics). (2010a), and (2016a). Household income and expenditure survey (HIES). Statistics and Information Management Division, Ministry of Planning, Government of Bangladesh.

BBS. (Bangladesh Bureau of Statistics). (2018). Statistical Yearbook of Bangladesh. Statistics Division, Ministry of Planning, Government of Bangladesh.

BBS. (Bangladesh Bureau of Statistics). (2016b). Statistical Yearbook of Bangladesh. Statistics Division, Ministry of Planning, Government of Bangladesh.

BBS (Bangladesh Bureau of Statistics). (2019). Statistical Yearbook of Bangladesh. Statistics Division, Ministry of Planning, Government of Bangladesh.

Bose, S. R. (1968). Trend of real income of the rural poor in East Pakistan. Pakistan Development Review, 8(3), 452-488.

Boyce, J. K., \& Ravallion, M. (1991). A dynamic econometric model of agricultural wage determination in Bangladesh. Oxford Bulletin of Economics and Statistics, 53(4), 361-376.

Campos, J., Ericsson, N. R., \& Hendry, D. F. (1996). Cointegration tests in the presence of structural breaks. Journal of Econometrics, 70(1), 187-220. https://doi.org/10.1016/0304-4076(94)01689-5.

Enders, W. (2010). Applied econometric times series. John Wiley \& Sons Inc, New York., 8, 199-207. https://doi.org/10.1016/S10432760(97)84344-5.

Engle, R., \& Granger, C. (1987). Co-Integration and Error Correction: Representation, Estimation, and Testing. Econometrica, 55(2), 251276. https://doi.org/10.2307/1913236.

Grosh, M., Andrews, C., Quintana, R. \& Rodriguez-Alas, C. (2011). Assessing safety net readiness in response to food Price volatility. Social Protection \& Labor, SP discussion paper no. 1118. https:// doi.org/10.1596/26825

Harris, R. \& Sollis, R. (2005). Applied Time Series. Modeling and Forecasting. Chichester: John Willey \& Sons, 2003, reprinted 2005.

Headey, D., Nisrane, F. B., Worku, I., Dereje, M. \& Taffesse, A. S. (2012). Urban wage behavior and food Price inflation: The case of Ethiopia, ESSP research notes 15, International Food Policy Research Institute (IFPRI).

Headey, D. (2014). Food prices and poverty reduction in the long run. Poverty, health, and nutrition division, IFPRI discussion papers no. 1331. International food policy research institute (IFPRI).

Hill, R., \& Genoni, M. E. (2019). Bangladesh poverty assessment: facing old and new Frontiers in poverty reduction (English). Washington, D.C.: World Bank Group. http://documents.worldbank.org/curated/ en/793121572582830383/Bangladesh-Poverty-AssessmentFacing-Old-and-New-Frontiers-in-Poverty-Reduction.

Hossain, A. A. (2008). Rural labour market developments, agricultural productivity, and real wages in Bangladesh, 1950-2006. The Pakistan Development Review, 47(1), 89-114. https://doi.org/10. 30541/v47ilpp.89-114.

Hossain, M. (2012). What implications does the world food price rise have for food security in Bangladesh. International Journal of Food and Agricultural Economics, 2(1), 51-63.

Ianchovichina, E. I., Loening, J. L., \& Wood, C. A. (2014). How vulnerable are Arab countries to global food price shocks. Journal of Development Studies, 50(9), 1302-1319.

Ivanic, M., \& Martin, W. (2008). Implications of higher global food prices for poverty in low-income countries1. Agricultural 
Economics, 39, 405-416. https://doi.org/10.1111/j.1574-0862. 2008.00347.x.

Ivanic, M., \& Martin, W. (2014). Short-and long-run impacts of food Price changes on poverty. The World Bank. https://doi.org/10. 1596/1813-9450-7011.

Jacoby, H. G. (2016). Food prices, wages, and welfare in rural India. Economic Inquiry, 54(1), 159-176.

Jayasuriya, S., Mudbhary, P. \& Broca, S. S. (2012). Food price spikes, increasing volatility and global economic shocks: Coping with challenges to food security in Asia. Food and Agriculture Organization of the United Nations. Bangkok. http://www.fao.org/docrep/016/ i3031e/i3031e 00.htm

Kalkuhl, M., Von Braun, J. \& Torero, M. (2016). Food price volatility and its implications for food security and policy, MPRA Paper No. 72164. https://mpra.ub.uni-muenchen.de/72164/ . Accessed 23 Jun 2016.

Khandker, S. R. \& Samad, H. A. (2016). Is seasonal hunger a distant memory in Bangladesh? Revisiting Earlier Evidences. Empirical study on risk and poverty in Bangladesh. Working paper no.110. JICA Research Institute https://www.jica.go.jp/jica-ri/publication/ workingpaper/jrft3q000000270a-att/JICA-RI_WP_No.110.pdf. Accessed 24 April 2017.

Lasco, C. D., Myers, R. J., \& Bernsten, R. H. (2008). Dynamics of rice prices and agricultural wages in the Philippines. Agricultural Economics, 38(3), 339-348.

Lewis, W. A. (1954). Economic development with unlimited supplies of labor. The Manchester School, 22(2), 139-119.

Liton, M. R., Akhter, R., \& Hasan, S. (2018). Impact of Minimum Wage on Employment and Exports in Readymade Garments in Bangladesh. Research on Humanities and Social sciences, 8, 18-23.

Maddala, G. S. \& Kim, I. M. (2007). Unit Roots, Cointegration, and Structural Change. Cambridge University Press, vol. 9. https://doi. org/10.1198/jasa.2001.s377 .

Martin, W. \& Ivanic, M. (2016). Food price changes, price insulation, and their impacts on global and domestic poverty. In Food Price Volatility and Its Implications for Food Security and Policy (pp. 101-113). Springer.

Murshid, K.A.S.M. \& Yunus, K.A.S. (2018). Rice prices and growth, and poverty reduction in Bangladesh. FAO, Rome, 2018. http://www. fao.org/publications/card/en/c/I8332EN .

Nonthakot P. \& Villano R.A. (2008). Migration and farm efficiency: Evidence from northern Thailand. AARES 52nd Annual Conference, Thailand, http://ageconsearch.umn.edu/bitstream/ $5981 / 2 / \mathrm{cp} 08$ no01. Accessed $10^{\text {th }}$ December 2015

Patterson, K. (2000). An introduction to applied econometrics. A Time Series Approach.

Pesaran, M. H., Shin, Y., \& Smith, R. J. (2001). Bounds testing approaches to the analysis of level relationships. Journal of applied econometrics, 16(3), 289-326.

Timmer, C. P. (1988). The agricultural transformation. Handbook of Development Economics, 1, 275-331.

Rashid, S. (2002). Dynamics of agricultural wage and rice price in Bangladesh: A re-examination. Markets and Structural Studies Division Discussion Paper No. 44. Washington, D.C. (USA): International food policy research institute.

Ravallion, M. (2006). Looking beyond averages in the trade and poverty debate. World Development, 34(8), 1374-1392. https://doi.org/10. 1016/j.worlddev.2005.10.015.

Von Braun J., Tadesse, G. (2012). Food security, commodity price volatility and the poor. Institutions and comparative economic development, International Economic Association Series. Palgrave Macmillan, London. https://doi.org/10.1057/9781137034014_16. 2012:298-312.

Wiggins, S. \& Keats, S. (2014.) Rural wages in Asia. Overseas Development Institute Report No. 49. http://www.odi.org/sites/ odi.org.uk/files/odi-assets/publications-opinion-files/9186.pdf

Tadesse, G., Algieri, B., Kalkuhl, M., \& Von Braun, J. (2016). Drivers and triggers of international food price spikes and volatility. In Food price volatility and its implications for food security and policy (pp. 59-82). Springer, Cham.

The World Bank Group. (2015). Food Price Watch, 19:8.

Zhang, X., Rashid, S., Ahmad, K., \& Ahmed, A. (2014). Escalation of real wages in Bangladesh: Is it the beginning of structural transformation? World Development, 64, 273-285. https://doi.org/10.1016/ j.worlddev.2014.06.015.

Zhang, X., Rashid, S., Ahmad, K., Mueller, V., Lee H. L, Lemma, S., Belal, S. \& Akhter, A. (2013). Rising wages in Bangladesh, IFPRI Discussion Paper no. 01249.

Zhenmin, L. (2018). Expanding Productive Capacity: Lessons Learned from Graduating Least Developed Countries. United Nations.

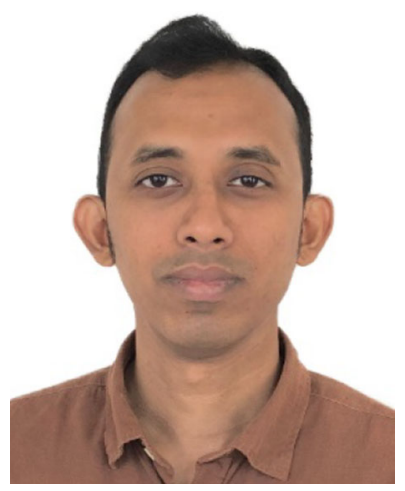

Md. Fuad Hassan is an Agricultural economist who has more than seven years of experience in agricultural research and policy analysis. He has worked with Bangladesh Agricultural University as an Assistant Professor in the Department of Agricultural and Applied Statistics. He is currently pursuing his doctoral research at the Center for Development Research (ZEF) in the University of Bonn.

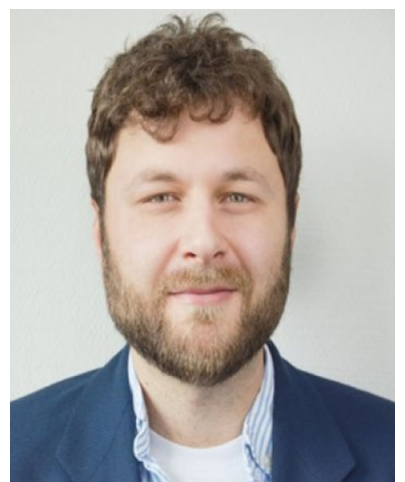

Lukas Kornher obtained his $\mathrm{PhD}$ from the University of Bonn in 2015. He has extensive work experience in food price volatility and markets in general. He is currently working at the University of Bonn's Center for Development Research (ZEF) as the Coordinator of the Food Monitor Project and Senior Research Fellow. He previously worked at the University of Kiel as a Post-Doctoral Researcher. 